
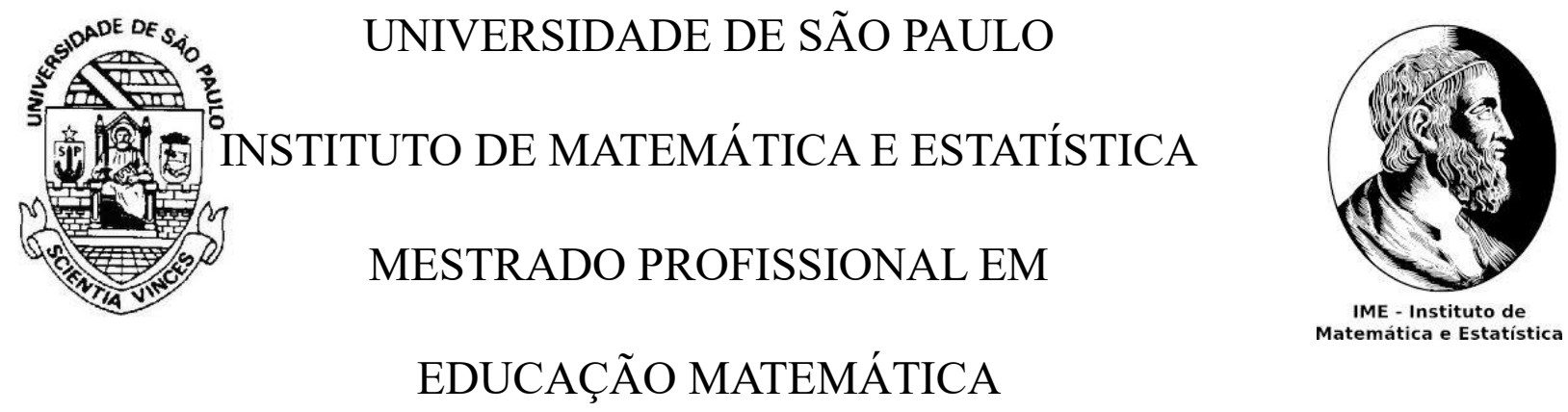

Concepções dos Alunos de Licenciatura em Matemática sobre o uso de Atividades de Investigação em suas Aulas

\author{
PAOLA BURGATT MENEGHESSO
}

SÃO PAULO

2017

UNIVERSIDADE DE SÃO PAULO

INSTITUTO DE MATEMÁTICA E ESTATÍSTICA

MESTRADO PROFISSIONAL EM EDUCAÇÃO MATEMÁTICA 


\title{
Concepções dos Alunos de Licenciatura em Matemática sobre o uso de Atividades de Investigação em suas Aulas
}

\author{
Dissertação apresentada ao Instituto de Matemática e \\ Estatística da Universidade de São Paulo para a obtenção \\ do título de Mestre em Educação Matemática.
}

\section{PAOLA BURGATT MENEGHESSO}

\section{Orientadora:}

Prof $^{\mathrm{a}}$. Dr ${ }^{\mathrm{a}}$. Bárbara Corominas Valério

SÃO PAULO

2017 
Dedico esta dissertação aos meus filhos Alexandre e Bruno, motivo para cada realização, razão para cada dia. 


\section{AGRADECIMENTOS}

À

Prof a . Dr a . Bárbara Corominas Valério,

Por sua contribuição competente e generosa para a realização deste trabalho.

Aos meus pais,

Anna e Radamés,

Por me ensinarem os valores que norteiam minha vida pessoal e profissional

Ao meu marido,

Pedro,

Pelos exemplos de dedicação à família e ao trabalho.

A todos os alunos de Licenciatura e professores que contribuíram respondendo aos questionários que viabilizaram esta pesquisa. 


\section{RESUMO}

MENEGHESSO, P.B. Concepções de Alunos de Licenciatura sobre o uso de Atividades de Investigação nas aulas de Matemática. Dissertação apresentada ao Programa de pós-graduação em Ensino de Matemática, do Instituto de Matemática e Estatística da Universidade de São Paulo, 2017.

Este trabalho analisa as concepções de alunos em formação, cursando Licenciatura em Matemática na Universidade de São Paulo, acerca do uso das atividades de investigação na sua prática profissional futura. $\mathrm{O}$ foco de nossa pesquisa pode ser representado pela questão: é possível estabelecer uma relação entre a formação e a disponibilidade do professor para a adoção de novas práticas, em especial, o uso de atividades de investigação, nas aulas de Matemática? O referencial teórico apoia-se principalmente no trabalho de Ponte, Brocardo e Oliveira (2003), no que se refere às atividades de investigação; em Fiorentini, Grando e Miskulin (2009), por seu trabalho com a formação de professores relacionada à pratica investigativa e em Onuchic (1999), por sua contribuição para análise do ensino-aprendizagem a partir da resolução de problemas, além dos Parâmetros Curriculares Nacionais (1998), principal documento que norteia o ensino de Matemática no Brasil. Para o desenvolvimento da pesquisa, classificada como mista, foram aplicados três questionários, cuja análise permitiu observar as concepções dos alunos de Licenciatura a respeito das condições de trabalho, de sua própria formação, de seu grau de confiança, vontade e disponibilidade para incluir as atividades de investigação em seus planejamentos, como professores de Matemática.

Palavras-chave: Investigação. Problemas. Matemática. Formação. 


\begin{abstract}
MENEGHESSO, P.B. Graduation Students' Conceptions about the use of Investigation Activities in Mathematics classes. Essay presented to The Mathematics Teaching Post-graduation Program, from the Mathematics and Statitics Institute, at the University of São Paulo, 2017.

This essay targets at analyzing the graduation students' conceptions, taking Mathematics Education at the University of São Paulo, about the use of investigative activities in their upcoming professional practices. The aim of our research can be represented by the inquiry: is it possible to establish any relations between the teachers education and their willingness for the adoption of new practices, especially, the use of investigation activities, in Mathematics classes? Reference is mainly supported by the work of Ponte, Bocardo and Oliveira (2003), for their work with teacher Education related to investigative practices, and by Onuchic (1999), for her contribution for the analysis of teaching and learning from problem-solving, besides The Brazilian National Curricular Parameters (1998), most important document to guide the Mathematics teaching practices in Brazil. For the survey development, considered as hybrid, three questionnaires were use, which analysis allowed us to observe Graduation students' conceptions about work conditions, about their own education process, about their confidence level, and willingness to include investigation activities in their class plans, as Mathematics teachers.
\end{abstract}

Key words: Investigation. Problem. Mathematics. Education. 


\section{SUMÁRIO}

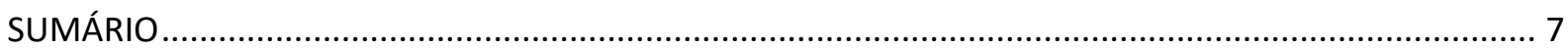

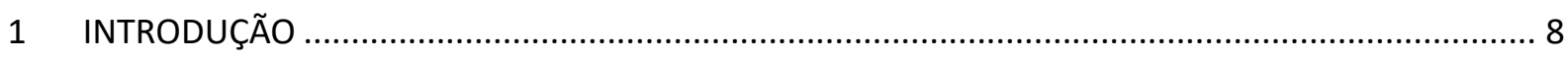

1.1 A expectativa em relação às novas práticas ............................................................ 10

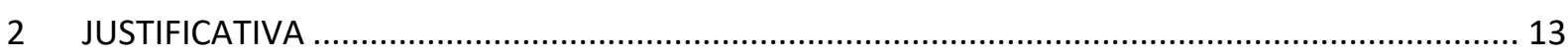

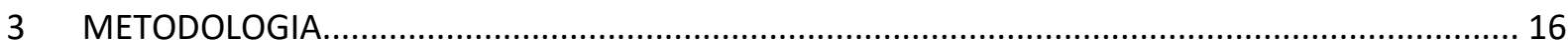

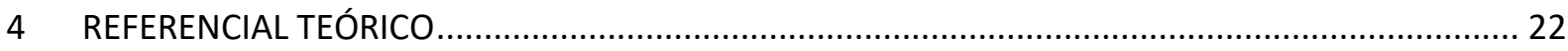

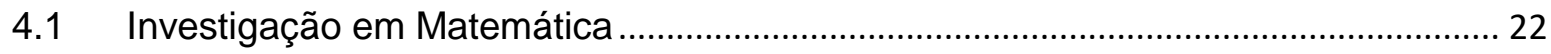

4.2 A Investigação Como Recurso Didático nas Aulas de Matemática.............................. 25

4.3 Exercícios, Problemas e Atividades de Exploração e de Investigação ...................... 29

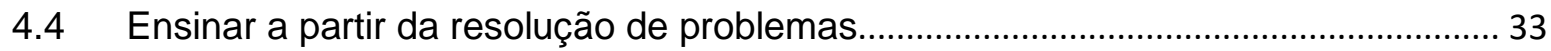

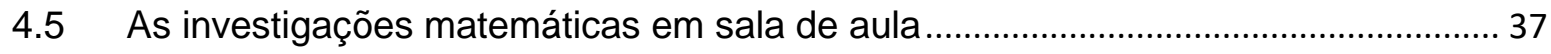

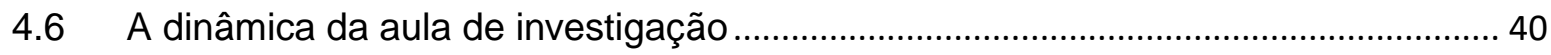

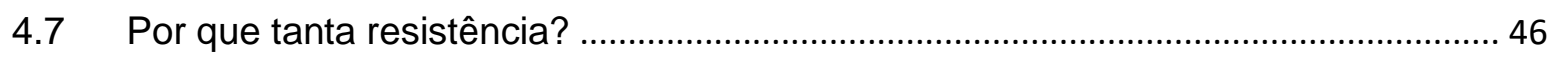

4.7.1 Algumas hipóteses para a resistência dos professores à inserção de

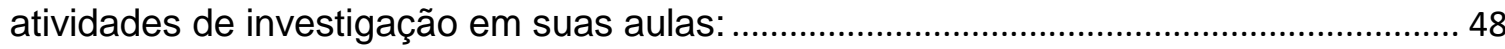

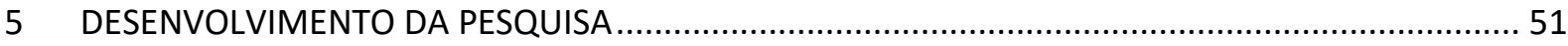

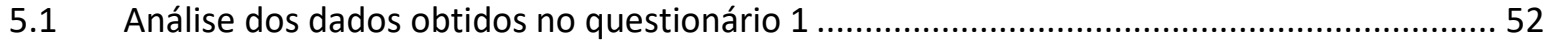

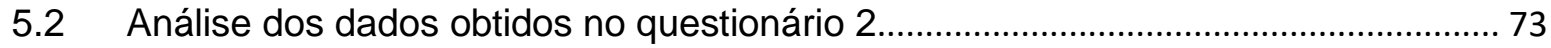

5.3 Análise dos dados obtidos no questionário 3.............................................................. 76

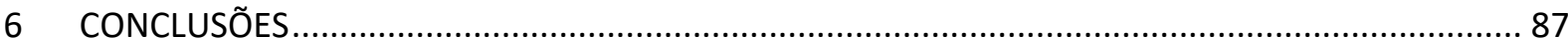

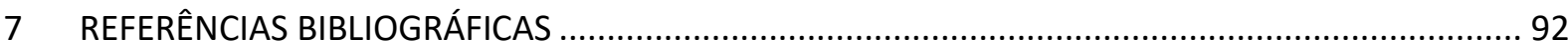

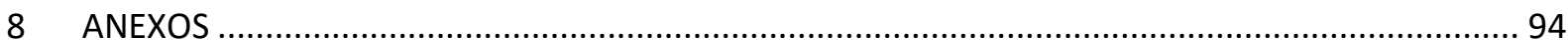




\section{INTRODUÇÃO}

O objetivo inicial desse trabalho era analisar os motivos pelos quais a prática investigativa ainda não é comum nas aulas de Matemática, ampliando a discussão sobre o ensino da disciplina no Ensino Fundamental II e levantando hipóteses para a resistência dos professores a esse tipo de proposta. Tal análise se faz pertinente quando levamos em conta que os documentos curriculares apontam fortemente para uma forma de ensinar protagonizada pelo aluno e que há consenso de que os cursos de formação e capacitação devam atuar no sentido de preparar os professores para essa prática.

Durante o percurso de pesquisa e escrita dessa dissertação, por inúmeras vezes, nos deparamos com a questão da formação de professores, o que fez com que voltássemos os olhos para esse aspecto como algo realmente relevante. Tornou-se necessário, então, explorar as visões dos alunos do curso de Licenciatura com o objetivo de usá-las para desenvolver e testar a aceitação das atividades de investigação nas aulas de Matemática.

Enquanto as orientações para a formação de professores caminham no sentido de tentar garantir que o futuro professor tenha condições para exercer as atividades ligadas ao ensino de Matemática, através de instrumentos como a articulação entre o ensino superior e a escola básica, previstos na Resolução n² de $01 / 07 / 2015^{1}$, persiste a questão: por que algumas práticas não se revelam na atuação dos professores que ensinam Matemática?

No item II do parágrafo $6^{\circ}$ do documento, lê-se: "O projeto de formação deve ser elaborado e desenvolvido por meio da articulação entre a instituição de educação superior e o sistema de educação básica, envolvendo a consolidação de fóruns estaduais e distrital permanentes de apoio à formação docente, em regime de colaboração, e deve contemplar a inserção dos estudantes de Licenciatura nas instituições de educação básica de ensino, espaço privilegiado para a práxis docente". (p.5)

Para argumentar a favor da formação do professor para a utilização das situações investigativas e da implementação desse tipo de atividade na prática 
dos professores já atuantes, apresentamos uma síntese dos argumentos documentados nas obras pesquisadas, que explicitam como as relações que o aluno estabelece nesse tipo de proposta favorecem uma maior compreensão dos conceitos matemáticos, das técnicas e procedimentos e do desenvolvimento de uma atitude reflexiva em relação à sua própria aprendizagem.

Documentos oficiais apontam para a necessidade de promover a significação dos conteúdos, buscando contextualizá-los de modo que a aprendizagem ocorra da forma mais natural e coerente possível. Nesse sentido, os PCN's destacam a "ênfase na resolução de problemas, na exploração da Matemática a partir dos problemas vividos no cotidiano e encontrados nas várias disciplinas" (BRASIL, 1998, p.20).

É importante ressaltar que os PCN's não usam o termo "investigação" para designar uma categoria de problemas. Apesar disso, se buscarmos as atividades didáticas que contribuem para o desenvolvimento da autonomia, da capacidade de abstração e argumentação, encontraremos ideias muito potentes na resolução de problemas. Em especial, quando estiverem aliadas a essas contribuições, o protagonismo do aluno, a explicação, a produção de justificativas, a validação e a comunicação de estratégias e resultados, estaremos no campo dos problemas de investigação.

Entretanto, no próprio documento, está relatado que a resolução de problemas não desempenha, nos currículos de Matemática, sua função mais relevante, de colocar o aluno diante de uma situação nova, ou seja, de iniciar novas aprendizagens: "Todavia, tradicionalmente, os problemas não têm desempenhado seu verdadeiro papel no ensino, pois, na melhor das hipóteses, são utilizados apenas como forma de aplicação dos conhecimentos adquiridos anteriormente pelos alunos" (BRASIL, 1998, p. 40).

Nesse contexto, define-se como objetivo de nossa pesquisa, estudar as concepções dos professores, tentando estabelecer uma relação entre a formação e a disponibilidade do professor para a adoção de novas práticas, em especial a investigativa, nos cursos de Matemática. 


\subsection{A expectativa em relação às novas práticas}

Cabe aos professores, diante das novas perspectivas apontadas pelos estudos em Educação Matemática, a tarefa de inserir novas atividades em seus planejamentos, respeitando as contribuições do ensino tradicional, de modo a atender a um novo tipo de demanda: ensinar a Matemática que prepare para a vida pessoal, profissional e para o exercício da cidadania. Resta, então, recorrer aos diferentes tipos de tarefas, explorando seu potencial pedagógico, buscando disparar novas aprendizagens através de problemas capazes de dar vida ao conteúdo a ser ensinado, lançando mão de antigas e novas práticas.

É inegável o valor, na aprendizagem de Matemática, do trabalho com algoritmos, da manipulação algébrica, das várias abordagens das operações matemáticas, do cálculo mental e de tantos outros aspectos já comuns no ensino da disciplina, mas é necessário instigar os alunos a realizar tarefas onde o que está em jogo é a compreensão desses e de tantos outros objetos de estudo, com a construção de relações autorais, que possam ser validadas ou, até mesmo, descartadas.

Não se trata, então, de abandonar todas as práticas escolares vigentes, mesmo as mais tradicionais - como as aulas expositivas, as explicações do professor, a prática através de exercícios - que continuam tendo grande valor no ensino de Matemática. Assim, uma das propostas desse trabalho, é apontar para aspectos que possam apoiar os professores já atuantes, ou em formação, na implementação de novos recursos didáticos. Nesse caso particular, as atividades de investigação.

Quanto aos professores em formação, muitos deles frequentaram a escola básica nos últimos anos, já sob a luz das novas propostas curriculares. Poderíamos supor que estariam mais capacitados para atuar em consonância com as propostas mais recentes da Educação Matemática. Será que podemos 
contar com uma geração de professores mais qualificados para trabalhar as situações de investigação com seus futuros alunos, nas aulas de Matemática?

Não corremos o risco de afirmar que se deseja adotar novas práticas, incorporando as orientações contidas nos estudos mais recentes da Educação Matemática e atendendo às orientações dos documentos oficiais. Então, temos que ter um olhar mais cuidadoso para o modo de ensinar Matemática nas escolas, principalmente no que se refere à atuação do professor.

O papel do professor, segundo Ponte (2003), é determinante nas aulas de investigação matemática. Cabe a ele incentivar a autonomia do aluno para que esse assuma a autoria da investigação e, ao mesmo tempo, garantir que o trabalho se desenvolva de maneira significativa, fazendo a mediação necessária para potencializar a aprendizagem. Dessa forma, abordar os temas escolares de modo a colocar o aluno como agente de seu próprio processo, pode ser bastante desafiador para o professor.

Por isso, é importante que os professores sintam-se capazes de incluir em seus planejamentos aulas de investigação como ponto de partida para novas aprendizagens, admitindo que isso pode contribuir para uma forma de ensinar em que as relações entre os conhecimentos prévios e o conhecimento em construção sejam estimuladas, atribuindo significado ao objeto de estudo. Propor problemas em que o aluno, a partir de suas hipóteses e argumentação, possa incorporar a seu repertório novas relações (autorais ou elaboradas por seu grupo) pode contribuir para ampliar a visão que o aluno tem acerca dos conceitos e procedimentos matemáticos.

Outro aspecto, não menos relevante, que também precisa estar contemplado na formação dos professores, é lidar com a questão atitudinal. Quando o professor entende que seu papel na formação integral do aluno vai além dos conteúdos puramente matemáticos, fica clara a preocupação em propiciar um ambiente em que, para além dos conteúdos, o aluno tenha que aprender, também, valores. Nesse sentido, na construção de um planejamento significativo e motivador, parece coerente incluir atividades de investigação, cujo desenvolvimento tem como pressuposto a interação respeitosa e cooperativa. 
Dentre os objetivos atitudinais propostos pelos PCN's, destacam-se: "Predisposição para usar os conhecimentos matemáticos como recurso para interpretar, analisar e resolver problemas em contextos diversos" e também o "Desenvolvimento da capacidade de investigação e da perseverança na busca de resultados, valorizando o uso de estratégias de verificação e controle dos resultados." (BRASIL, 1998, P.91)

Diante dos argumentos e das considerações apresentadas, o desenvolvimento desse trabalho associou à pesquisa teórica e questionários, buscando ouvir professores com diferentes experiências e expectativas, na intenção de entender suas concepções a respeito do uso das atividades de investigação em suas aulas. 


\section{JUSTIFICATIVA}

Tenho visto, ao longo de minha história pessoal e profissional, uma dicotomia em relação ao apreço pela Matemática. Entre muitos adultos da minha geração, há uma verdadeira aversão à Matemática. Não há meio termo, quem não gosta, odeia! Para muitos, a Matemática é um território inóspito, desprovido de sentido, regido por cálculos e relações obscuras, quase sempre inúteis. Porém, aqueles que gostam apresentam certo encantamento pela elegância das demonstrações, pela precisão e clareza da linguagem, pela harmonia e pelos aspectos artísticos da Geometria.

Transitei por todas as séries do Ensino Fundamental II na minha trajetória como professora. Acumulei experiências e frustrações nesses 25 anos de vida profissional. Tornei-me mais reflexiva em relação à minha própria atuação e mais preocupada em formar alunos que possam exercer sua cidadania de forma crítica e plena.

Reconheço que a escola mudou. Os estudantes hoje parecem estar mais confortáveis e confiantes com a Matemática escolar. Apesar de ainda persistir o discurso do "pra quê eu tenho que saber isso?", as mudanças curriculares e a atuação dos professores e das instituições parecem interferir positivamente no grau de apreço que a nova geração tem pela Matemática.

Porém, nem tudo se resume à afinidade do aluno com a disciplina. Transitando pelo Ensino Fundamental II é comum ouvir os professores comentarem sobre o crescente desinteresse dos alunos pela Matemática, à medida que os conteúdos tornam-se mais abstratos e que as situações de contexto intra-matemático tornam-se mais frequentes. Independente do grau de apreço pela Matemática, persiste a preocupação com o desempenho dos alunos brasileiros nas avaliações nacionais e internacionais, persiste a dificuldade em lidar com "a formação integral do cidadão", persiste a angústia com a busca de significado para os conteúdos escolares.

$\mathrm{Na}$ tentativa de entender melhor essas dificuldades, o que se observa, segundo Machado (2011), é uma série de justificativas e diagnósticos que, 
apesar de fundamentados, não se convertem em mudanças efetivas na prática dos professores que ensinam Matemática.

Alguns afirmam que as dificuldades resultam de certas características intrínsecas da Matemática. Sendo um tema que envolve constantemente o recurso à abstração, ela exigiria de seus aprendizes e praticantes algumas aptidões peculiares, inatas. Outros pretendem que a origem dos problemas é de natureza didática e esta associada a metodologias arcaicas, hoje inadequadas. 0 que se observa, no entanto, é que muitas das novas metodologias representam apenas modificações periféricas nas práticas tradicionais, revestidas de uma linguagem mais atraente. Há quem culpe os currículos, acusando-os de insuficiente atualização, o que conduziria a uma cristalização nos conteúdos apresentados. Mas as sucessivas propostas curriculares, nos mais diferentes países, não têm sido suficientes para alterar significativamente o panorama. Aos que concentram as criticas na insuficiente apresentação de aplicações práticas para os conteúdos ensinados, mas as crianças continuam a gostar muito de contos de fadas, distantes da vida cotidiana, e a fazer pouco caso dos conceitos matemáticos. Há ainda os que depositam suas fichas na falta de interesse dos alunos, ou em dissonâncias psicológicas na aprendizagem escolar, mas os alunos não são inapetentes em todos os temas, demonstrando grande entusiasmo com certos temas extraescolares. (p.179)

Foi na busca de situações de aprendizagem mais favoráveis ao ensino que iniciei um trabalho mais consistente com uso de projetos e, para o desenvolvimento dos projetos, o uso de situações de investigação. Atualmente, 
apesar de ainda trabalhar com projetos, acredito que as atividades de investigação podem prescindir deles, podem se dar em contextos intramatemáticos, contextualizados ou não, desde que bem fundamentados dentro do universo que o aluno reconhece como significativo. Para elucidar, apelo a um exemplo cotidiano: se a turma está estudando potências, por que não investigar o expoente zero ao invés de apresentar o clássico "qualquer número elevado a zero dá resultado 1?".

Reconheço que, inicialmente, não ter o controle total das aulas, trabalhar com situações abertas, ter grupos diferentes atuando com diferentes demandas foi bastante assustador. Mas também tenho que admitir que mediar tais situações de aprendizagem contribuiu para ampliar minha visão sobre o ensino de Matemática, na medida em que ajudar os alunos no desenvolvimento de estratégias próprias e auxiliá-los na autorregulação de seu processo leva o professor, inevitavelmente, a rever sua prática e a adotar uma postura mais reflexiva sobre sua atuação profissional.

Essa forma de trabalho foi muito influenciada, na época, pelas ideias da Teoria das Situações Didáticas de Guy Brousseau e por uma convicção pessoal de que estimular a vivência, as situações de ação, formulação, validação e institucionalização faria uma diferença significativa na qualidade da aprendizagem para meus alunos. Também, nessa época, tínhamos, na escola onde trabalhava, uma assessoria externa. A partir do estudo dos documentos curriculares brasileiro e argentino e as atividades ali propostas, com grande participação dos alunos, foi-se abrindo um leque de novas possibilidades. Parecia, na época, e ainda parece hoje, que essa forma mais democrática de encarar o ensino de Matemática abarcava uma quantidade maior de alunos, dando legitimidade à aprendizagem, através da coautoria, da interação alunoaluno e aluno-professor.

Em última análise, justifico que a escolha desse tema é tanto pedagógica quanto política, na medida em que um ensino de qualidade, para todos, só se justifica quando o professor enxerga, em sua prática, uma preocupação com o cidadão que ajuda a formar. É preciso encorajar os alunos, mostrar-Ihes que são capazes de produzir conhecimento, de atuar de forma 
consciente e crítica no seu próprio processo de aprendizagem, de argumentar sobre suas estratégias e adotar uma atitude respeitosa e responsável sobre sua produção e a de seus pares.

\section{METODOLOGIA}

Para verificar as concepções dos alunos do curso de Licenciatura sobre o uso de atividades de investigação nas aulas de Matemática, foram levantadas questões e hipóteses a serem pesquisadas. Nesse sentido, a presente pesquisa se enquadra no conceito de pesquisa exploratória, definida por Creswell como "a técnica em que o pesquisador tende a basear as alegações de conhecimento em elementos pragmáticos (por exemplo, orientado para consequência, centrado no problema e pluralista). Essa técnica emprega estratégias de investigação que envolvem coleta de dados simultânea ou sequencial para melhor entender os problemas de pesquisa. A coleta de dados também envolve a obtenção tanto de informações numéricas (por exemplo, em instrumentos), como de informações de texto (por exemplo, em entrevistas), de forma que o banco de dados final represente tanto informações qualitativas quanto quantitativas." (p.35)

O objetivo dessa pesquisa de métodos mistos foi entender melhor o grau de aceitação e a disponibilidade dos alunos de Licenciatura pesquisados para 
trabalhar com atividades de investigação em suas aulas. Para isso, foram analisadas as quantidades de respostas obtidas para os itens pesquisados e, também, aspectos qualitativos, como justificativas, explicações e comentários presentes nas questões abertas.

Esta pesquisa classifica-se ainda como exploratória, pois "tem o propósito de proporcionar maior familiaridade com o problema, com vistas a torná-lo mais explícito, ou a construir hipóteses. Seu planejamento tende a ser bem flexível, pois interessa considerar os mais variados aspectos relativos ao fato ou fenômeno estudado". (GIL, 2010, p.27)

O desenvolvimento deste trabalho envolveu pesquisa bibliográfica, que é elaborada com base em material já publicado. Isso inclui, segundo Gil, "material impresso, como livros, pesquisas, jornais, teses, dissertações e anis de eventos científicos." (2010, p.29)

Também foi utilizada a pesquisa documental, pois foram utilizadas, neste estudo, resoluções e documentos elaborados por órgãos públicos, como o Ministério da Educação e Cultura, por exemplo.

Além disso, foram aplicados questionários, em três momentos, buscando responder às questões que se apresentavam à medida que a pesquisa bibliográfica avançava, na tentativa de confirmar hipóteses, de delimitar melhor o objeto de estudo ou de simplesmente conhecer o perfil profissional e pessoal dos alunos de Licenciatura pesquisados. A identidade dos pesquisados foi preservada, conforme combinado com eles, por não ser um aspecto relevante para a pesquisa.

A opção pelo questionário se justifica por sua abrangência, pela possibilidade de ser respondido por vários indivíduos ao mesmo tempo. No nosso caso, na presença, mas sem a intervenção, do aplicador. Houve momentos de interação com os pesquisados, que estão descritos ao longo do trabalho, mas as respostas produzidas foram individuais e autorais, preservando a confiabilidade dos resultados obtidos.

O primeiro questionário foi aplicado em 01/04/2016 para os alunos da disciplina MAT0450 "Seminários de Resolução de Problemas", do curso de 
Licenciatura em Matemática da Universidade de São Paulo. A escolha desse grupo deu-se em razão de estarem estudando, justamente, o potencial pedagógico do ensino a partir da resolução de problemas (tema central para o desenvolvimento desta dissertação).

Os objetivos de MAT0450 são "Fazer com que os alunos vivenciem situações problema variadas. Promover o desenvolvimento do potencial do aluno como resolvedor de problemas e sua autonomia de pensamento matemático, o que envolve, pelo menos: formular conjecturas, estabelecer conexões, validar soluções e procedimentos, comunicar ideias com clareza. Discutir o papel do uso da resolução de problemas na produção do conhecimento matemático e no processo de ensino/aprendizagem dessa ciência." ${ }^{1}$ Com objetivos tão próximos daqueles que fundamentam a prática investigativa, pareceu apropriado questionar os licenciandos sobre seu grau de aproximação com o tema.

A quantidade de respostas favoráveis á prática investigativa pareceu discrepante com a realidade apontada na pesquisa bibliográfica, o que nos levou a querer entender melhor o que acontece depois que os alunos de Licenciatura concluem seus cursos e se tornam profissionais da educação.

Isso não era, exatamente, o objetivo inicial do trabalho, que não fazia uma distinção tão rígida entre professores em formação e já formados. Porém, como foi dito na introdução, a pesquisa bibliográfica apontava para a questão da formação enfatizando que mudanças propostas e aceitas na teoria não se revelam na prática profissional dos professores. Tornou-se importante, então, compreender o que acontece depois de concluída a Licenciatura. Essa "mudança de rumo" é, segundo Gil, algo inerente ao processo de pesquisa:

O tema de pesquisa de modo geral é formulado de maneira muito ampla, não favorecendo, portanto, a definição de um problema em condições de ser pesquisado. O levantamento bibliográfico preliminar é que irá possibilitar que a área de estudo seja delimitada e que

\footnotetext{
${ }^{1}$ Disponível em https://uspdigital.usp.br/jupiterweb/obterDisciplina?sgldis=mat0450\&nomdis=
} 
o problema possa, finalmente, ser definido. $O$ que geralmente ocorre é que, ao longo dessa fase, o estudante acaba selecionando uma subárea de estudo que, por ser mais restrita, irá possibilitar uma visão mais clara do tema de sua pesquisa e, consequentemente o aprimoramento do problema de pesquisa. Pode ocorrer também que o levantamento bibliográfico venha a determinar uma mudança nos propósitos iniciais da pesquisa, pois o contato com o material já produzido sobre o assunto deixará mais claro para o pesquisador as dificuldades para tratá-lo adequadamente. (2010, p.47)

Com a análise dos resultados desse primeiro questionário, pareceu importante construir uma nova pesquisa, também em forma de questionário, para verificar o que acontece na prática, com professores que já concluíram seus cursos.

O segundo questionário foi enviado por e-mail a mais de 30 professores, com diferentes experiências profissionais, que atuam em diferentes escolas, públicas ou privadas. Aqui, não era importante o tipo de instituição de ensino, nem as características sociais ou econômicas de seus alunos. O objetivo era verificar se o uso de atividades de investigação continuaria tendo uma aceitação tão positiva quanto à observada no grupo de professores em formação.

Por motivos desconhecidos, apenas 6 dos professores que receberam o questionário retornaram o e-mail com as respostas. Porém esse grupo, ainda que pequeno, defendeu o uso de atividades de investigação nas aulas de Matemática. Minha hipótese é que ocorreu algo inusitado. Teriam respondido ao questionário apenas os professores que se identificam com o tema. Aqueles cuja afinidade justificaria a colaboração para o sucesso da pesquisa. Não foi possível concluir sobre a posição dos professores entrevistados porque aqueles que responderam podem não representar 0 pensamento dos professores. 
De qualquer forma, ainda que reduzido, o perfil desse grupo é de profissionais preocupados com a qualidade do ensino, atuantes em relação à sua própria formação, reflexivos em relação à sua prática. Sua contribuição, inicialmente pensada como material de pesquisa, serviu de pano de fundo para a elaboração de um novo questionário, que tomou como base as respostas produzidas por esses seis professores para incitar a reflexão dos alunos do curso de Licenciatura.

O terceiro questionário foi aplicado em 15/08/2017 numa turma de MAT1500, "Projetos de Estágio", disciplina anual oferecida para alunos a partir do terceiro ano da Licenciatura. A intenção deste questionário era verificar as concepções desses alunos a respeito da prática investigativa levando em conta os depoimentos dos professores (obtidos no questionário 2), a experiência dos licenciandos como estagiários, visto que, na ocasião, já tinham cursado o primeiro semestre da disciplina MAT1500 e uma vivência de atividade de investigação conduzida em pela pesquisadora.

A escolha desse grupo de alunos da Licenciatura deu-se em função de eles estarem envolvidos na elaboração e aplicação de projetos que são aplicados em salas de aula do ensino básico, projetos estes desenvolvidos juntamente com o professor da escola e sob a supervisão do professor responsável pela disciplina. Durante as aulas, vários temas ligados a esta dissertação são discutidos pelos alunos.

É interessante observar que os professores da escola onde os projetos são desenvolvidos também acompanham as aulas de MAT1500 e que, no dia da aplicação do questionário, tínhamos presentes 4 professores da rede pública de ensino que responderam ao mesmo.

Segue o Programa de MAT 1500: "A idéia de projeto e a sala de aula como espaço de investigação; o uso de projetos no ensino de Matemática; questões de metodologia do ensino de Matemática: Resolução de Problemas, Modelagem Matemática, jogos, materiais de manipulação estruturados ou não; Reflexões sobre obstáculo didáticos, aprendizagem significativa, o papel do "erro", avaliação. Elaboração de projetos sobre temas de Matemática do 
Ensino Básico. Aplicação supervisionada dos mesmos em classes de professores participantes do curso de extensão. Discussão e avaliação coletiva dos resultados."

A última etapa de trabalho consistiu em tabular, confrontar, descrever e interpretar as respostas obtidas, na tentativa de verificar as concepções dos alunos de Licenciatura sobre o uso de atividades de investigação nas aulas de Matemática, objeto desta dissertação.

\footnotetext{
${ }^{2}$ Disponível em https://uspdigital.usp.br/jupiterweb/obterDisciplina?sgldis=mat1500\&nomdis=
} 


\section{REFERENCIAL TEÓRICO}

\subsection{Investigação em Matemática}

Na obra "Investigações Matemáticas na Sala de Aula", Ponte, Oliveira e Brocardo definem: "Investigar é procurar conhecer o que não se sabe" (p.13). No mesmo parágrafo, discorrem sobre o sentido da palavra investigar em vários contextos, inclusive em outros idiomas, sempre relacionando o uso dessa palavra a atividades como pesquisar, inquirir, procurar informações.

Nas atas do Encontro Nacional dos Professores de Matemática de Portugal (Profmat), Lisboa, 1998, encontramos uma explicação, que, apesar de fugir do formalismo das definições, esclarece a perspectiva de Ponte sobre a atividade de investigar: "Na minha perspectiva, "investigar" não é mais do que procurar conhecer, procurar compreender, procurar encontrar soluções para os problemas com os quais nos deparamos. Trata-se de uma capacidade de primeira importância para todos os cidadãos e que deveria permear todo o trabalho da escola, tanto dos professores como dos alunos."(p.2)

Em artigo publicado pela Revista Iberoamericana de Educação Matemática, UNIÓN em março de 2010 - número 21 - Ponte esclarece:

Investigar, em Matemática, inclui a formulação de questões, que frequentemente evoluem à medida que o trabalho avança. Investigar, envolve, também, a produção, a análise e o refinamento de conjecturas sobre estas mesmas questões. E, finalmente, envolve a demonstração e a comunicação dos resultados. O ponto de partida para uma investigação pode ser um problema matemático ou uma situação não-matemática (tanto de uma outra ciência e da tecnologia, como da organização social ou da vida diária). Quando procuramos obter uma melhor percepção da situação, estamos a "explorá-la". Mais tarde, quando nossa pergunta é formulada de modo claro, dando unidade ao 
trabalho, podemos dizer que temos um problema. A realização de uma investigação matemática envolve processos conscientes e inconscientes, sensibilidade estética, conexões e analogias com problemas matemáticos e situações não matemáticas.(p.15)

Para melhor compreensão do que se pretende ao propor uma tarefa de investigação é necessário pensar sobre como preparar o aluno para assumir o papel do investigador. Para isso, vamos nos ater um pouco aos procedimentos envolvidos na atividade do pesquisador. Claro que, para os matemáticos profissionais $^{3}$, a relação com o objeto de estudo é diferente daquela verificada nas aulas com alunos do Ensino Fundamental, por isso vamos discorrer sobre dois pontos de vista: o dos matemáticos profissionais e outro sobre a investigação como tarefa matemática, possível para alunos não especialistas.

Sobre isso, Ponte, Brocardo e Oliveira (2003) escrevem: "para os matemáticos profissionais, investigar é descobrir relações entre objetos matemáticos conhecidos ou desconhecidos, procurando identificar as respectivas propriedades" (p.13). Eles sintetizam, no quadro que reproduzimos abaixo, os quatro momentos da realização de uma investigação rigorosa, mas esclarecem que as etapas não são estanques, podendo se desenvolver simultaneamente, e, ainda, que cada momento pode incluir mais de uma etapa.

\begin{tabular}{|l|l|}
\hline $\begin{array}{l}\text { Exploração e formulação de } \\
\text { questões }\end{array}$ & $\begin{array}{l}\text { - Reconhecer uma situação como } \\
\text { problemática, }\end{array}$ \\
& - Explorar a situação problemática, \\
& - Formular questões \\
\hline Conjecturas & $\begin{aligned} \text { - Organizar dados, } \\
\text { - Formular conjecturas (e fazer } \\
\text { afirmações sobre uma conjectura) }\end{aligned}$ \\
\hline Testes e reformulação & $\begin{array}{l}\text { - Realizar testes } \\
\text { - Refinar a conjectura }\end{array}$ \\
\hline Justificação e avaliação & - Justificar uma conjectura \\
& - Avaliar o raciocínio ou o resultado do \\
\hline
\end{tabular}




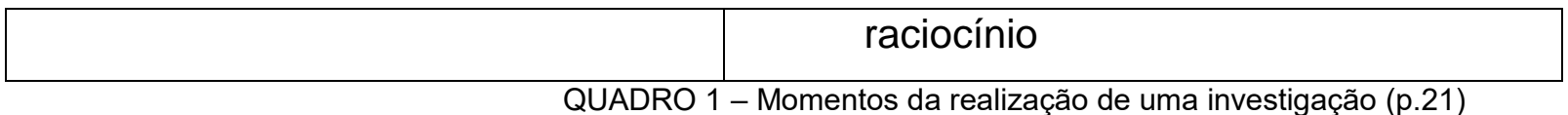

QUADRO 1 - Momentos da realização de uma investigação (p.21)

É interessante observar que, quando pensamos no conceito de investigação como elemento de ensino e aprendizagem, realizado com alunos, muitos dos aspectos acima mencionados se conservam, porém sem 0 formalismo que a Matemática rigorosa exige.

$\mathrm{Na}$ atividade matemática realizada pelos alunos, as investigações devem merecer um lugar destacado. As investigações matemáticas permitem a formulação de conjecturas, a avaliação de sua plausibilidade, a escolha dos testes adequados para sua validação ou rejeição. Permitem ainda procurar argumentos que demonstrem as conjecturas que resistiram a diversos testes e levantar novas questões para investigar. Traduzem assim o trabalho desenvolvido pelos matemáticos profissionais, ou, por outras palavras, o processo de criação matemática que é inerente ao que é Matemática e ao que significa saber Matemática (ABRANTES, PONTE, FONSECA e BRUNHEIRA, 2003, p.71)

Há, portanto, um elemento importante que não pode ser ignorado. No trabalho de investigação realizado pelo aluno, é ele quem assume, da formulação à justificação, a responsabilidade pelo desenvolvimento da tarefa. Durante esse processo, ele age como o matemático profissional, reproduzindo - dentro do seu universo de aluno do ensino fundamental - o que, historicamente, aconteceu com a produção do conhecimento matemático e de tantas outras ciências. Convidar o aluno a agir como pesquisador pode revelar

\footnotetext{
${ }^{3}$ Usamos aqui a expressão "matemático profissional" no sentido utilizado por Ponte, para designar pessoas que trabalham com a Matemática, como pesquisadores, por exemplo.
} 
potencialidades que dificilmente seriam descobertas em situações comuns nas aulas de Matemática.

Além disso, há um aspecto social que não pode ser ignorado, pois em uma aula em que todos participam da construção de um conhecimento, está presente uma forma mais democrática de aprender. Isso traz legitimidade ao conteúdo e coloca o aluno em outro papel diante de seus colegas e da escola, além de contribuir para o desenvolvimento de novas perspectivas em relação à sua atuação na sociedade. Em entrevista concedida à Revista Nova escola em dezembro de 2009, Brousseau afirma "Se todos tiverem acesso à cultura Matemática, sabendo elaborar perguntas e hipóteses como fazem os profissionais da área, será mais fácil que exijam explicações e discutam se determinada justificativa é verdadeira ou falsa".

\subsection{A Investigação Como Recurso Didático nas Aulas de Matemática}

Para entender melhor o papel das atividades de investigação nas aulas de matemática é necessário esclarecer, primeiro, os diferentes tipos de tarefas que podem ser propostas. Ponte, em artigo publicado em 2010 pela revista UNIÓN, organiza as tarefas em quatro tipos, levando em conta o grau de complexidade, a estrutura, o contexto referencial e o tempo requerido para sua resolução. Essa organização está sintetizada no quadro abaixo:

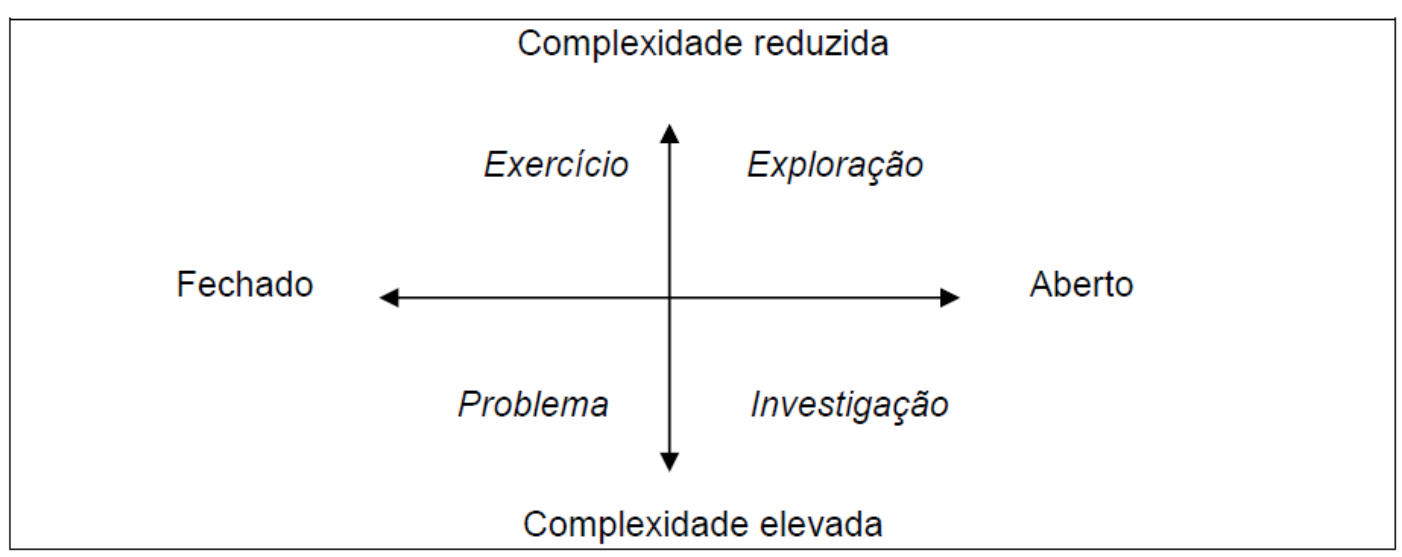

Revista Iberoamericana de Educación Matemática UNIÓN, número 21- p.21 
O esquema indica que, em contraposição aos exercícios, que são tarefas de complexidade reduzida e estrutura fechada, temos as situações de investigação, como tarefas exigentes, com complexidade elevada e estrutura aberta. Os problemas também têm estrutura fechada, mas seu nível de complexidade é mais alto que o dos exercícios. Quanto às explorações, podem ser realizadas com mais frequência, pois, apesar de terem estrutura mais aberta, seu nível de complexidade não é alto, sendo mais facilmente realizada pelos alunos, apesar de apresentar um tipo de desafio que não se apresenta nos problemas e exercícios de estrutura fechada. Ainda é necessário esclarecer que no mesmo artigo Ponte explica que "muitas vezes não distingue as atividades de exploração e investigação, chamando-se de "investigação" a todas elas" (p.21). Isso ocorre pois é muito sutil a diferença entre as duas, podendo, inclusive, depender do contexto escolar no qual as atividades são desenvolvidas.

Uma síntese dessa classificação dos quatro tipos de tarefa se encontra no parágrafo abaixo:

Os exercícios e os problemas têm uma coisa em comum. Em ambos os casos, o seu enunciado indica claramente o que é dado e o que é pedido. Não há margem para ambiguidades. A solução é sabida de antemão pelo professor, e a resposta do aluno está certa ou errada. Numa investigação as coisas são um pouco diferentes. Trata-se de situações mais abertas - a questão não está bem definida no início, cabendo, a quem investiga um papel fundamental na sua definição. E uma vez que os pontos de partida podem não ser exatamente os mesmos, os de chegada também podem ser diferentes. (PONTE, BROCARDO E OLIVEIRA, 2003, p.23)

Ainda sobre os tipos de tarefa, Ponte considera que as quatro são 
importantes e devem ter seu espaço garantido nas aulas de Matemática. Segue abaixo transcrição da resposta dada à questão "Quais os tipos de tarefas que devem ser priorizados nas aulas?" durante o VI SHIAM ${ }^{4}$ :

O exercício tem um desafio reduzido e também tem uma estrutura mais fechada. Nós, então, valorizamos a realização dos quatro tipos de tarefa, mas aquilo que constatamos é que na maior parte dos casos, professores propõem exercícios, às vezes um ou outro problema, mas achamos que é muito importante ter uma variedade. Sobretudo as tarefas de exploração são tarefas muito valiosas no ponto de vista de promover a aprendizagem. É claro que também as tarefas de investigação devem ter seu lugar, mas é mais fácil e viável propor tarefas de exploração com uma certa frequência.

Quando perguntado sobre a diferenciação entre as atividades de exploração e de investigação, o próprio Ponte afirma que é muito subjetiva. Segue abaixo transcrição da resposta dada a essa questão durante o VI SHIAM $^{4}$

Inicialmente usávamos apenas investigação, mas depois percebemos que é um termo um bocadinho ambicioso, que atemorizava os professores, que tinha uma carga muito forte.

Então criamos uma divisão entre investigação $e$ exploração, que são ideias muito próximas, mas no fundo a exploração é um pouco mais acessível.

4 (Seminário de investigações de/em aulas de Matemática), que aconteceu de 17/07/2017 a 19/07/207, na UNICAMP, Campinas/SP: 
É claro que esses conceitos são muito relativos aos alunos, uma matéria que para um aluno pode ser uma exploração, para outro pode ser um exercício, pois ele já sabe fazer essa tarefa muito bem, e portanto, digamos que o que fazemos atualmente em nosso dia a dia é reservar o termo investigação para tarefas com nível de desafio mais elevado e que nós fazemos mais raramente. Explorações são tarefas que nós fazemos com muita frequência em muitas aulas e, portanto, são mais acessiveis aos alunos, mais especificamente aos pequenos grupos.

Outro importante documento norteador para esse trabalho, os PCN's, apontam, como um dos objetivos gerais para o ensino fundamental, referências para a prática investigativa: "Identificar os conhecimentos matemáticos como meios para transformar o mundo à sua volta e perceber o caráter de jogo intelectual, característico da Matemática, como aspecto que estimula o interesse, a curiosidade, o espírito de investigação e o desenvolvimento da capacidade para resolver problemas." (BRASIL, 1998, p.47).

Cabe, aqui, um esclarecimento. Em nenhum momento os PCN's indicam o trabalho com investigações Matemáticas na sala de aula, no sentido aqui abordado. Porém, há várias indicações para os professores no sentido de promover um tipo de trabalho que muito se aproxima da prática investigativa proposta por Ponte. O trabalho com problemas é amplamente estimulado, mas não há essa diferenciação ou classificação entre os tipos de tarefas e problemas. 


\subsection{Exercícios, Problemas e Atividades de Exploração e de Investigação}

Para melhor delimitar o objeto de estudo desse trabalho, vamos discorrer um pouco mais sobre algumas tarefas desenvolvidas nas aulas de Matemática. O que aqui denominamos tarefas são as atividades propostas pelo professor e realizadas pelos alunos no processo de ensino-aprendizagem. Há diversos tipos de tarefas que podem ser realizadas pelos alunos, como ler, interpretar, resumir, etc. Porém, dentre as tarefas características da Matemática, vamos explicitar melhor as contidas no quadro proposto por Ponte.

Consultando a bibliografia, é possível descrever com maior grau de detalhamento as características desses três tipos de atividades - problemas, exercícios e atividades de investigação - a partir do tipo de proposta e do trabalho intelectual envolvido para sua realização pelos estudantes. Porém, há o quarto tipo, as atividades de exploração, cuja diferenciação é tão tênue que faz com que outros estudiosos, como é o caso de Fiorentini, Fernandes e Cristóvão (2005) utilizem a expressão "tarefas explorarório-investigativas" quando se referem às situações que contemplem tanto a exploração quanto a investigação.

Ponte esclarece que uma mesma tarefa pode ter níveis de desafios diferentes para diferentes alunos, o que não permite que a tarefa guarde, em si, as características necessárias para ser enquadrada em uma ou outra categoria. Porém, constrói um quadro com atividades de diferentes naturezas, no sentido de caracterizar atividades que são potencialmente exercícios, problemas ou investigação: "É de notar que as características de uma tarefa não são absolutas mas relativas à pessoa que a realiza. Uma mesma questão pode ser para uma pessoa um problema e para outra um exercício, etc."(Atas do Profmat, 1998) 
No mesmo documento, Ponte volta a esclarecer: "Muitas vezes não se distingue entre tarefas de investigação e de exploração, chamando-se "investigações" a todas elas. Isso acontece, muito provavelmente, porque é complicado saber à partida qual o grau de dificuldade que uma tarefa aberta terá para um certo grupo de alunos. No entanto, uma vez que atribuímos importância ao grau de dificuldade das tarefas, é preferível termos uma designação para as tarefas abertas mais fáceis e outra designação para as mais difíceis".

O documento traz um exemplo para ajudar na compreensão dos tipos de tarefas:

\begin{tabular}{lll}
\hline \multicolumn{1}{c}{ Exercício } & \multicolumn{1}{c}{ Problema } & \multicolumn{1}{c}{ Tarefa de investigação } \\
\hline Simplifica: & $\begin{array}{l}\text { Qual o mais pequeno } \\
\text { número inteiro que, } \\
\text { dividido por 5, 6 e 7 dá } \\
\text { sempre resto 3? }\end{array}$ & $\begin{array}{l}\text { 1. Escreve a tabuada dos 9, } \\
\text { desde 1 até 12. Observa os } \\
\text { algarismos das diversas } \\
\text { colunas. Encontras alguma } \\
\text { regularidade. }\end{array}$ \\
b) $\frac{6 \times(10-7)}{17-2}=$ & $\begin{array}{l}\text { 2. Vê se encontras } \\
\text { regularidades nas tabuadas } \\
\text { de outros números. }\end{array}$ \\
c) $\frac{20}{(15-9) \times 2}$ & & \\
\hline
\end{tabular}

Atas do Profmat 2003 - p.4

Exercícios serão aqui considerados como atividades que envolvem familiarização, repetição, aplicação de técnicas e algoritmos. Nesse tipo de atividade o aluno sabe exatamente o que deve ser feito, os enunciados não precisam ser interpretados, pois revelam prontamente a tarefa que deve ser executada, como em "efetue" ou "fatore" ou "resolva a equação" (no exemplo acima, "simplifique"). A natureza da dificuldade aqui é relacionada ao emprego da técnica adequada, ou a questões de cálculo. Os exercícios servem, dessa forma, para consolidar um conhecimento já adquirido pelo aluno, para desenvolver destreza na aplicação de procedimentos ou para auxiliar na mecanização de técnicas. 
Segundo D'Amore (2007) "tem-se um exercício quando a resolução prevê que se devam utilizar regras e procedimentos já aprendidos, ainda que não consolidados. Os exercícios, portanto, entram na categoria das experiências com objetivo de verificação imediata ou de reforço" (p.286)

Problemas são diferentes, pois envolvem conceitos e procedimentos que exigem algum grau de decisão por parte do aluno, pois a situação não está totalmente delimitada, como nos exercícios. Assim, o ensino a partir da resolução de problemas teria potencial para desenvolver potencialidades como relacionar, analisar e comunicar conhecimentos matemáticos, contribuindo para a formação de alunos mais capazes e atuantes.

No exemplo acima, é pedido ao aluno que encontre o menor número que tenha resto 3 quando dividido por 5,6 ou 7 . Há diferentes modos de abordar esse problema, o aluno poderá dispor de seu repertório de conhecimentos prévios sobre divisibilidade, ou apelar ao algoritmo da divisão, ou ainda fazer tentativas. Independente da estratégia, no sentido de Ponte, é uma questão fechada, com uma pergunta bem definida: Qual é o menor número?

Quanto à definição de problema, ainda segundo D'Amore, 'tem-se, por outro lado, um problema quando uma, ou mais, das regras, ou um ou mais dos procedimentos necessários ainda não estão na bagagem cognitiva do responsável por resolvê-lo; na ocasião, algumas dessas regras ou alguns desses procedimentos poderiam estar inclusive em via de explicitação; às vezes, é a própria sucessão de operações necessárias para resolver o problema que demandará um ato criativo por parte de quem precisa resolvê-lo." (p.286)

Vamos comentar, agora, as questões de investigação. Quando o aluno deve organizar uma tabela com a tabuada do 9 , desde $9 \times 1$ até $9 \times 12$, para observar suas regularidades, e ainda estender suas conclusões para outras tabuadas. Perceba que essa é uma questão totalmente aberta. $\mathrm{O}$ que o aluno está procurando? Que tipo de regularidade se espera que ele perceba? Pode ser que o próprio professor não consiga antecipar todas as observações de seus alunos. 
Quanto às atividades de exploração, elas constituiriam um nível intermediário. Mesmo se tratando de tarefas abertas, seu grau de complexidade não é tão elevado. $\mathrm{O}$ aluno tem uma situação mais delimitada. $\mathrm{O}$ grau de decisão não é tão elevado. Mesmo assim, a tarefa requer uso de estratégias pessoais, explicações e justificativas.

Uma atividade de exploração sobre o mesmo conteúdo seria, por exemplo, a proposta de Sadovsky (2011, p.32):

"Numa tabela de 6 colunas e "infinitas" linhas vão se posicionando consecutivamente o zero e "todos"os números naturais:

\begin{tabular}{|l|l|l|l|l|l|}
\hline 0 & 1 & 2 & 3 & 4 & 5 \\
\hline 6 & 7 & 8 & 9 & 10 & 11 \\
\hline 12 & 13 & 14 & 15 & 16 & 17 \\
\hline 18 & 19 & 20 & 21 & 22 & 23 \\
\end{tabular}

a) Em que

linha e em que coluna se encontra o número $126 ?$

b) Que número se encontra na linha 9, coluna 2?

c) Cite dois números maiores que 1000, localizados na mesma coluna que 0 130.

d) Que número se encontra na linha 37, coluna 3?

e) Onde se encontra o número 27643 ?

f) Segundo o mesmo critério, elabore outra tabela, mas com 7 colunas. Em que coluna estará o 126? Nesta segunda tabela, que número ficará na linha 8 , coluna 4 ?

Segue também o exemplo de atividade de exploração dado por Ponte em Actas do Profmat, Lisboa (1998, p. 7) : 
1. Repara que $2^{2}=4$ e que $2 \times 2=4$.

- Será sempre verdade que $\mathrm{a}^{\mathrm{n}}=\mathrm{a} \times \mathrm{n}$ ?

- Experimenta nos seguintes casos e noutros por ti escolhidos, usando, se necessário, a calculadora.
$0^{2}=$
$0 \times 2=$
$10^{2}=$
$10 \times 2=$
$4^{2}=$
$\left(\frac{1}{2}\right)^{3}=$
$\left(\frac{1}{2}\right) \times 3=$
$3^{3}=$
$\left(\frac{5}{3}\right)^{4}=$
$\left(\frac{5}{4}\right) \times 4=$

2. Determina cada uma das seguintes potências

$\begin{array}{lll}10^{3} & 1^{4} & 0.45^{2} \\ 10^{5} & 1^{8} & 0.45^{4} \\ 10^{6} & 1^{18} & 0.45^{7}\end{array}$

- Se calculasses $10^{7}$, seria maior ou menor que $10^{6}$ ?

- E se calculasses $0.45^{9}$ seria maior ou menor que $0.45^{7}$ ?

- O que se passa com as potências de base 1 ?

- De todo o estudo que fizeste, podes tirar alguma conclusão?

3. Repara que $4^{2}=16 \mathrm{e} 2^{4}=16$. Será sempre verdade que $\mathrm{a}^{\mathrm{n}}=\mathrm{n}^{\mathrm{a}}$ ?

- Experimenta noutros casos!

4. Sabendo que $3^{6}=729$, és capaz de calcular imediatamente $3^{7}$ ? e $3^{8}$ ? e $3^{12}$ ?

\subsection{Ensinar a partir da resolução de problemas}

Pela importância dada à aprendizagem a partir da resolução de problemas nos estudos recentes da Educação Matemática e por serem as atividades de investigação, objeto dessa dissertação, uma categoria específica de problemas, vamos nos ater um pouco nesse ponto.

Como referência será utilizado o artigo de Onuchic, intitulado "Ensinoaprendizagem de Matemática Através da Resolução de Problemas", publicado na obra "Pesquisa em Educação Matemática: Concepções e Perspectivas". Nessa publicação ela faz um panorama histórico do papel da resolução de problemas no desenvolvimento do ensino de Matemática. Segue uma breve 
síntese comentada dessas ideias:

A resolução de problemas sempre teve relevância no desenvolvimento do saber matemático, desde a antiguidade, em várias culturas. De fato, seja por questões de ordem prática ou recreativa, a história da Matemática sempre nos remete à resolução de problemas. Quase impossível, aqui, não pensar nas fontes clássicas, como os problemas do Papiro de Rhind ou as questões ligadas à Geometria, na Grécia Antiga.

Com o passar do tempo e as mudanças na forma da sociedade se organizar e produzir, a importância de ensinar Matemática nas escolas tornouse cada vez maior, assumindo características próximas do que conhecemos hoje. Vale ressaltar que, com essa evolução, tornou-se necessário desenvolver metodologias que permitissem ensinar a todos e não só a pequenos grupos, com necessidades específicas. É nesse contexto que começam os estudos sobre como promover tal aprendizagem.

No início do século $\mathrm{XX}$, os problemas escolares ainda tinham características que mais se aproximam dos exercícios, pois seguiam um modelo a ser reproduzido, ainda que contextualizado. Em linhas gerais, apresentava-se um problema e sua solução. A isso se seguia uma lista de problemas semelhantes, cuja resolução deveria seguir os passos apresentados. O que reduzia, a tarefa de resolver problemas à aplicação e mecanização de processos.

Em 1945 algo realmente importante parece ter ocorrido com a publicação do livro "How to solve it" de George Polya. A partir daí, vários estudos foram desenvolvidos no sentido de explorar a potencialidade dos problemas no ensino-aprendizagem de Matemática. Polya defendia que não se pode dizer ao aluno o que pensar ou o que fazer, que o papel do professor era o de ensinar o aluno a pensar por conta própria.

Os desdobramentos de seu trabalho e de tantos outros que vieram a seguir caminham na mesma direção e impactaram a forma de encarar a resolução de problemas. Atualmente, os estudos de Educação Matemática indicam que aluno deve ser estimulado a desenvolver estratégias pessoais 
para resolver problemas matemáticos. O saber matemático, os conceitos e procedimentos, devem ser desenvolvidos a partir da resolução de problemas.

Sobre a resolução de problemas, escreve Onuchic:

“A importância dada à resolução de problemas é recente e somente nas últimas décadas é que educadores matemáticos passaram a aceitar a ideia de que o desenvolvimento da capacidade de se resolver problemas merecia mais atenção. A caracterização da Educação Matemática, em termos da Resolução de Problemas, reflete uma tendência de reação a caracterizações passadas como um conjunto de fatos, domínio de procedimentos algorítmicos ou um conhecimento a ser obtido por uma rotina ou por exercício mental. Hoje, a tendência é caracterizar esse trabalho considerando os estudantes como participantes ativos, os problemas como instrumentos precisos e bem definidos e a atividade na resolução de problemas como uma coordenação complexa simultânea de vários níveis de atividade." (in BICUDO, p.203)

Consonantes com os objetivos descritos nos PCN's, as teorias construtivistas também incentivam o trabalho com resolução de problemas e tiveram grande aceitação no Brasil. Em ambos os casos, os conhecimentos prévios do aluno devem ser valorizados. Em oposição à atitude passiva, o aluno deve ser estimulado a construir a partir desses conhecimentos, buscar explicações e procedimentos, ouvir, pensar, explicar, justificar. Espera-se que o aluno seja agente importante de sua aprendizagem, use sua criatividade e seja capaz de enfrentar situações novas, não apenas reproduzir soluções já pensadas por outras pessoas. Há um grande estimulo ao pensamento. Segundo a autora, "o aluno tanto aprende matemática resolvendo problemas como aprende matemática para resolver problemas. A resolução de problemas não é mais um processo isolado."(p.210 e 211). 
Porém, não há garantias de um engajamento dos professores e instituições em uma prática centrada na resolução de problemas. Há iniciativas de professores, ou grupos de professores, de buscar conhecimentos e assumir uma atitude mais reflexiva, para desenvolver práticas pedagógicas mais eficientes. Segundo Onuchic, "essas iniciativas não chegam a atingir o conjunto de professores e, por isso, não chegam a alterar o quadro desfavorável que caracteriza o ensino de matemática no Brasil”. E continua, analisando a formação dos professores: "A formação de professores, tanto inicial quanto continuada, pouco tem contribuído para qualificá-los para o exercício da docência." (p.213)

Ainda sobre a formação de professores para a implementação de novas práticas, Sadovsky afirma em entrevista concedida à Revista Nova escola ( 2007) "Falta formação aos docentes para aprofundar os aspectos mais relevantes, aqueles que possibilitam considerar os conhecimentos anteriores dos alunos, as situações didáticas e os novos saberes a construir."

A pesquisadora defende que é preciso aumentar a participação das crianças na produção do conhecimento, pois elas não suportam mais regras e técnicas que não fazem sentido. "O caminho é um só e passa pela prática reflexiva e pela formação continuada."

Esses estudos nos remetem, novamente, a questionar a formação e a disponibilidade dos professores para um ensino a partir da resolução de problemas. Apesar de encontrarmos inúmeros estudos publicados sobre o tema resolução de problemas, surgem várias questões quando esses problemas envolvem investigação: Seriam as atividades de investigação uma alternativa viável para promover a aprendizagem nas aulas de Matemática? 0 que é necessário para que alunos e professores desenvolvam as condições necessárias para explorar o potencial desse tipo de tarefa? É uma questão de formação, como sugerem as pesquisadoras mencionadas? 


\subsection{As investigações matemáticas em sala de aula}

Sobre as atividades de investigação nas aulas de Matemática, identificamos elementos que são fundamentais e que se diferem da maneira como, tradicionalmente, a disciplina Matemática é abordada nos cursos de Ensino Fundamental. Importante salientar que, o que tratamos como "tradicional", é a maneira como normalmente as tarefas são conduzidas, deixando os problemas como fechamento, e não início da aprendizagem, por exemplo, ou dando importância excessiva à aplicação de regras. Nesse tipo de conduta, o professor planeja se curso priorizando técnica e mecanização em detrimento da discussão e da compreensão. Não se trata, também, de abandonar todas as práticas vigentes, mas de garantir que haja espaço para a reflexão sobre novas formas de ensinar e aprender.

Segundo Sadovsky (2007) "Os aspectos mais interessantes da disciplina, como resolver problemas, discutir ideias, checar informações e ser desafiado, são pouco explorados na escola. O ensino se resume a regras mecânicas que ninguém sabe, nem o professor, para que servem."

O primeiro elemento fundamental, como já dissemos, é que quando o aluno é encorajado a agir como um matemático profissional, pode entender melhor como se estrutura o pensamento matemático. Quando resolve exercícios e problemas, certamente não lhe são exigidos os processos de exploração, formulação de conjecturas, testes e justificação, mas quando investiga um problema, o aluno precisa assumir o protagonismo da situação. A 
implicação do aluno no processo é fator decisivo na aprendizagem.

Vale ressaltar que investigar é uma tarefa que valoriza os conhecimentos prévios do estudante, uma vez que se trata de um trabalho exploratório em que cada um levará consigo seu repertório pessoal. Sob esse ponto de vista, a questão atitudinal torna-se extremamente relevante, pois o aluno será convidado, em vários momentos, a questionar suas ideias e até a abrir mão de alguma em favor de outra que seja mais interessante ou mais adequada para a resolução do problema proposto.

Outro elemento característico das aulas de investigação é o envolvimento integral do aluno, que divide com o professor a responsabilidade sobre a aprendizagem, desde a formulação até a resolução do problema e a comunicação das conclusões.

Na disciplina Matemática, como em qualquer outra disciplina escolar, o envolvimento ativo do aluno é uma condição fundamental de aprendizagem. 0 aluno aprende quando mobiliza seus recursos cognitivos e afetivos com vista a atingir um objetivo. Esse é, precisamente, um dos aspectos fortes das investigações. Ao requerer a participação do aluno, na formulação das questões a estudar, essa atividade tende a favorecer o seu envolvimento na aprendizagem (PONTE, BROCARDO e OLIVEIRA p. 23).

A investigação pressupõe um contexto colaborativo, pois mesmo que inicialmente envolva uma tarefa individual, haverá a necessidade, em algum momento, de validar ou expor os resultados. Compartilhar experiências, pequenos avanços e até tentativas frustradas de resolver um problema pode ajudar o aluno a sistematizar o conhecimento e aproximar-se de novos conceitos. 
A troca de estratégias inerente a esse processo amplia as possibilidades do grupo de enfrentar a situação em estudo e cria melhores condições para situações futuras. Nesse sentido, é uma prática se retro alimenta - quanto mais o aluno investiga, mais cria condições para investigar.

No ensino tradicional de Matemática, os alunos nem sempre são convidados a formular questões, conjecturas, argumentar, justificar. Esses são verbos que vários professores já têm o hábito de conjugar, mas que muitos ainda resistem em incorporar às suas práticas.

Podemos conjecturar que professores que têm uma posição de maior protagonismo no processo de elaboração do currículo têm mais facilidade de encontrar modos de integrar nesse mesmo currículo experiências de natureza investigativa para seus alunos. O professor para quem o currículo está em constante desenvolvimento, em função das necessidades de seus alunos, é mais natural valorizar a participação destes no processo de construção do conhecimento matemático, do que aquele que encara o currículo como uma simples listagem de conteúdos a transmitir. "(OLIVEIRA, PONTE, BROCARDO e BRUNHEIRA, in ABRANTES, PONTE, FONSECA e BRUNHEIRA, p.100) 


\subsection{A dinâmica da aula de investigação}

Para melhor elucidar o que é uma aula de investigação, estão organizadas, no quadro abaixo, as etapas percorridas por alunos e professores, bem como os significados de cada uma dessas etapas, Segundo Ponte, Brocardo e Oliveira (2003, p.25). Essa síntese é uma interpretação pessoal das informações contidas no texto, não constituindo, assim, uma citação:

\begin{tabular}{|c|c|c|c|}
\hline ETAPA & $\begin{array}{l}\text { O QUE ACONTECE } \\
\text { NESSA ETAPA }\end{array}$ & PAPEL DO ALUNO & $\begin{array}{ll}\text { PAPEL } & \text { DO } \\
\text { PROFESSOR }\end{array}$ \\
\hline $\begin{array}{l}\text { Introdução da } \\
\text { Tarefa } \\
\text { "O arranque da } \\
\text { aula" }\end{array}$ & $\begin{array}{l}\text { O professor faz a } \\
\text { proposta à turma, } \\
\text { oralmente ou por } \\
\text { escrito, deixando } \\
\text { claro o que se espera } \\
\text { deles no decurso da } \\
\text { atividade. }\end{array}$ & $\begin{array}{l}\text { Certificar-se de ter } \\
\text { entendido } \\
\text { proposta, } \\
\text { Colocar suas } \\
\text { dúvidas quanto à } \\
\text { proposta. }\end{array}$ & $\begin{array}{l}\text { Apresentar a } \\
\text { proposta de forma } \\
\text { clara e precisa, } \\
\text { Desafiar os alunos, } \\
\text { Incentivar a } \\
\text { participação de } \\
\text { todos. }\end{array}$ \\
\hline $\begin{array}{l}\text { Realização } \\
\text { tarefa }\end{array}$ & $\begin{array}{l}\text { Os alunos realizam a } \\
\text { investigação }\end{array}$ & $\begin{array}{l}\text { Envolver-se } \\
\text { tarefa, }\end{array}$ & $\begin{array}{ll}\text { Apoiar os alunos na } \\
\text { construção } & \text { da }\end{array}$ \\
\hline
\end{tabular}




\begin{tabular}{|c|c|c|c|}
\hline $\begin{array}{l}\text { "O } \\
\text { desenvolvimento } \\
\text { do trabalho" }\end{array}$ & $\begin{array}{ll}\text { individualmente, em } & \text { eques } \\
\text { pequenos } & \text { ou } \\
\text { grandes grupos. } & \end{array}$ & $\begin{array}{l}\text { Contribuir com seus } \\
\text { colegas, } \\
\text { Propor estratégias, } \\
\text { formular hipóteses, } \\
\text { testar, validar, } \\
\text { invalidar, } \\
\text { argumentar. }\end{array}$ & $\begin{array}{l}\text { autonomia para o } \\
\text { trabalho, } \\
\text { Ajudar na dinâmica } \\
\text { dos grupos, } \\
\text { Colocar questões } \\
\text { que ajudem os } \\
\text { alunos a avançar }\end{array}$ \\
\hline $\begin{array}{l}\text { Discussão dos } \\
\text { resultados } \\
\text { "A discussão da } \\
\text { investigação" }\end{array}$ & $\begin{array}{l}\text { Os alunos relatam } \\
\text { aos colegas de turma } \\
\text { o trabalho realizado. } \\
\text { Sistematização das } \\
\text { principais ideias. }\end{array}$ & $\begin{array}{l}\text { Comunicar as } \\
\text { descobertas do } \\
\text { grupo de forma clara } \\
\text { e precisa. }\end{array}$ & $\begin{array}{l}\text { Incentivar o registro } \\
\text { escrito } \\
\text { generalização, } \\
\text { Garantir que os } \\
\text { alunos } \\
\text { justificar } \\
\text { conclusões, } \\
\text { Atuar } \\
\text { moderador. }\end{array}$ \\
\hline
\end{tabular}

Durante o desenvolvimento desse trabalho, foi se tornando cada vez mais relevante dar atenção à questão da comunicação. Como se pode observar no quadro acima, em todas as etapas ocorre algum tipo de interação (entre professor e aluno, entre alunos, em duplas ou grupos, com a classe toda). É uma situação comunicativa intensa, do ponto de vista da oralidade e, posteriormente, do registro escrito.

A importância da comunicação é analisada por Sadovsky:

Como toda disciplina, o trabalho com a Matemática oferece um modo específico de construir uma 
relação com a verdade. Estabelece-se, assim, um aspecto central no seu valor formativo. E nessa construção a produção de explicações por parte dos alunos se torna um aspecto obrigatório. Longe de ser uma aquisição espontânea, e longe também de ser um assunto que os docentes podem ensinar de forma declarada, conseguir fazer que as crianças expliquem - relacionar, deduzindo sentenças para validar o trabalho que vão realizando - será resultado de convidá-las a participar de maneira contínua de um cenário no qual explicar seja uma prática cotidiana. Um cenário no qual a atividade Matemática mesma seja o objeto de ensino. ${ }^{5}$

Durante o desenvolvimento do trabalho, o aluno participa dessa comunicação, seja ouvindo, argumentando, testando hipóteses, buscando exemplos ou contra exemplos, relatando, sistematizando as ideias.

Também é importante salientar a necessidade da aquisição da linguagem matemática através do registro escrito, pois se fazem necessárias, muitas vezes, a argumentação e a formalização escritas de regras ou conceitos, estratégias e resultados.

O estímulo à capacidade de ouvir, discutir, escrever, ler ideias matemáticas, interpretar significados, pensar de forma criativa, desenvolver o pensamento indutivo/dedutivo, é o caminho que vai possibilitar a ampliação da capacidade para abstrair elementos comuns a várias situações, para fazer conjecturas, generalizações e deduções simples como para o aprimoramento das representações, ao mesmo tempo em que permitirá aos alunos irem se conscientizando da importância de

\footnotetext{
${ }^{5}$ Texto retirado da obra 30 Olhares para o Futuro, publicado pela Escola da Vila, disponível em http://www.vila.com.br/html/outros/2010/30_anos/pdf_30/30_textos/24_patricia.pdf
} 
comunicar ideias com concisão. (BRASIL,1998, p. 23)

Nas etapas citadas anteriormente, "O arranque da aula", "O desenvolvimento do trabalho" e "A discussão da investigação", a comunicação ocorre em diferentes níveis.

No arranque, seja por uma instrução oral ou escrita, o professor apresenta a proposta que, ainda que inacabada (visto que é uma situação aberta, cuja formulação final fica a critério do aluno), consiste da informação da qual dependerá todo o processo subsequente. Assim, a comunicação, nesse momento, é fundamental para que o aluno possa "entrar na tarefa", assumindo o papel do investigador.

Já na etapa do desenvolvimento o aluno assume totalmente a tarefa. Aqui, a comunicação se intensifica entre o estudante e o objeto de estudo. Nessa etapa, a atuação do professor tem como objetivo mediar a relação entre o aluno, ou os alunos, e o problema estudado. Assim, a comunicação entre professor e aluno, ou do aluno com seus pares, nessa etapa, precisa ser muito cuidadosa, para garantir o protagonismo dos alunos, incentivar a participação de todos e potencializar a aprendizagem.

É essa, também, a etapa mais favorável para que o professor estimule seus alunos a pensar matematicamente, superando eventuais dificuldades que tenham com o conteúdo que se está estudando ou com conteúdos já estudados. Sobre isso, afirmam Ponte, Brocardo e Oliveira (2003): "Numa aula de investigação é muito provável, e desejável, que o professor raciocine matematicamente e de modo autêntico..." (p.49) e ainda, "Deve existir, por parte do professor, uma predisposição para manifestar, perante os alunos, o seu raciocínio matemático. Mediante o modelo do professor, os alunos podem aprender muito sobre aspectos fundamentais do processo investigativo."(p.50).

Quando ocorre a discussão da investigação, a situação comunicativa é outra. Nessa etapa, os alunos já discutiram com seus pares, criaram estratégias, testaram hipóteses, chegaram a uma solução consensual e estão prontos a confrontar suas conclusões com as de outros grupos. Ganham força 
a capacidade de argumentar, justificar e provar. Não se trata de um debate, mas de uma apresentação de ideias fundamentadas e legitimadas pelos integrantes do grupo.

Pensando na questão da comunicação, na última etapa fica evidenciada a importância de conseguir produzir boas sínteses, seja para o próprio registro matemático da atividade, seja para tornar mais eficiente o compartilhamento de estratégias. Quando, para além da compreensão, o aluno é desafiado a comunicar o que aprendeu, é necessário avançar para outro nível, mais abstrato e reflexivo.

Em todas as etapas, é importante que o professor seja aquele que coloca a pergunta certa para balizar o trabalho. Ponte (2003) diz que o professor é o "inquiridor", responsável por favorecer que ideias potentes sejam valorizadas, ajudando os alunos a raciocinar matematicamente. Questões simples, do tipo "como você pensou?" ou "mas, isso vale sempre ou só nesse caso?" podem ajudar os alunos na compreensão dos aspectos matemáticos envolvidos e fazê-los avançar no sentido de desenvolver maior rigor em sua argumentação.

Além de ajudar colocando questões, é muito importante que o professor incentive seus alunos a formularem suas próprias perguntas, pois o aluno investigador deve desenvolver autonomia para questionar-se, o tempo todo, acerca da questão estudada. Sobre isso, Machado (2011) escreve:

Convém registrar que, na escola, os alunos costumam ser mais induzidos a darem respostas do que formularem perguntas. Todas as caricaturas da escola - algumas bem grotescas - resumem a atividade do professor à mera formulação de questões a serem respondidas pelos alunos. O desenvolvimento da inteligência, no entanto, está mais diretamente relacionado à capacidade de fazer as perguntas pertinentes relativamente ao tema, as perguntas que realmente interessam, do que fornecer as respostas certas a perguntas oriundas de interesses que não são nossos, ou que não fomos levados a fazê-los 
nossos. (p.195)

Ainda segundo Ponte, Brocardo e Oliveira, é muito importante garantir o fechamento da atividade. É na última etapa que se dá a formalização dos conteúdos estudados. Ao chegarem a esse ponto, os alunos já tiveram muitas oportunidades de explorar o problema e de apreciar as estratégias de seus pares. Estão prontos a decidir e registrar suas conclusões, escrever regras, sínteses e provas de seus argumentos. É muito importante garantir que haja tempo para essa fase do trabalho.

Em última análise, uma aula de investigação tem um potencial para educar para além da aquisição dos conhecimentos matemáticos propriamente ditos. A possibilidade de ouvir e argumentar de maneira aberta e respeitosa, de construir coletivamente um conhecimento, muitas vezes tendo que abrir mão de suas hipóteses iniciais, configura-se numa prática democrática, numa forma estruturada de praticar o debate de ideias e posições. Estimular esse tipo de atividade nas aulas de Matemática pode contribuir para desenvolver o espírito crítico e a autoconfiança dos alunos. 


\subsection{Por que tanta resistência?}

O simples fato de dar à resolução de problemas seu devido lugar como disparador de novas aprendizagens, já representaria uma inversão no quadro atual do ensino de Matemática, marcado pela reprodução de procedimentos e técnicas. É nesse contexto da resolução de problemas, que se inserem as atividades de investigação, como uma alternativa potente para promover o ensino de conteúdos conceituais, procedimentais e atitudinais.

Segundo Fiorentini, Grando e Miskulin (2009):

O uso de investigações matemáticas em sala de aula pode contribuir para a emergência de uma prática similar àquela vivida pelos matemáticos quando estão em processo de produção ou criação do conhecimento matemático. Essa prática geralmente difere daquela realizada por eles quando ensinam Matemática. 0 matemático, quando ensina Matemática, tende a seguir o modelo euclidiano de sistematização desse conhecimento e a concepção platônica de Matemática. Por isso, prefere adotar uma sequência didática que se inicia pelas definições e proposições ou pelos teoremas e suas demonstrações, para, só então, apresentar exemplos e ilustrações e, depois, propor exercícios de fixação e problemas de aplicação. 
Além disso, as obras utilizadas na pesquisa apresentam argumentos consistentes no sentido de enfatizar que professores devem oferecer aos alunos uma diversidade de propostas e contextos que possibilitem 0 desenvolvimento de capacidades que, para muito além dos conteúdos, ajudem os alunos a agir de forma consciente e crítica, visando a formação integral do cidadão.

Temos que considerar também que os alunos da atualidade pouco têm em comum com os do passado, e não podem mais ser encarados como "receptores" do conhecimento. Com seu enorme potencial para lidar com a tecnologia e super estimulados pelo excesso de informação, os estudantes de hoje não precisam de quem lhes transmita conhecimento, mas de professores capazes de mediar a relação entre o aluno e o objeto de estudo, ajudando a filtrar e organizar tais informações de modo a propiciar o envolvimento e o desenvolvimento de estratégias.

Lê-se, também, nos PCN's: “Em contrapartida à simples reprodução de procedimentos e ao acúmulo de informações, educadores matemáticos apontam para a resolução de problemas como ponto de partida da atividade matemática. Essa opção traz implícita a convicção de que o conhecimento matemático ganha significado quando os alunos têm situações desafiadoras para resolver e trabalham para desenvolver estratégias de resolução." (BRASIL, p.39/40).

Não erramos em afirmar, então, que existe uma preocupação tanto com a formação dos professores quanto com a necessidade de colocar essa formação a serviço de mudanças que impactem positivamente o ensino de Matemática nas escolas brasileiras. Também não há garantias que ações de formação se revelem na prática profissional de quem ensina. Mas podemos tentar entender melhor os mecanismos de formação e qualificação para que, uma vez oferecidos, possam se traduzir em ações assertivas no ensino de Matemática.

Ainda que muitos professores assumam uma postura bastante reflexiva em relação à sua atuação profissional, buscando novos conhecimentos e capacitação, constantemente, ainda há, quem não procure cursos de formação 
continuada. Mesmo entre aqueles que se atualizam, não há garantias de que irão incorporar, mesmo que gradativamente, novas práticas à sua rotina. Todavia, é preciso enfatizar que esse problema não é novo. Ao descrever o "Quadro atual do ensino de Matemática no Brasil", em 1998, lemos nos PCN'S: "Entre os obstáculos que o Brasil tem enfrentado em relação ao ensino de Matemática, aponta-se a falta de formação profissional qualificada, as restrições ligadas às condições de trabalho, a ausência de políticas educacionais efetivas e as interpretações equivocadas de concepções pedagógicas". (p.21)

\subsubsection{Algumas hipóteses para a resistência dos professores à inserção de atividades de investigação em suas aulas:}

A seguir, apresentamos algumas hipóteses para a resistência dos professores à adoção de novas práticas, em especial a investigativa, e as justificativas teóricas que amparam a elaboração de algumas delas:

1. A prática investigativa pressupõe o protagonismo do aluno. Nesse sentido, o professor deve abrir mão do controle daquela atividade didática em alguns momentos, o que pode ser muito perturbador.

2. Aspectos ligados à disciplina e gestão da sala de aula. Propor atividades que necessitem de discussão e argumentação pode gerar um ambiente nocivo ao desenvolvimento de um bom trabalho. 


\begin{abstract}
Sobre 1 e 2
Pode sempre programar-se o início de uma aula de investigação, mas nunca se sabe como ela irá acabar. A variedade de percursos que os alunos seguem, seus avanços $e$ recuos, as divergências que surgem entre eles, o modo como as turmas reagem às intervenções do professor são elementos altamente imprevisíveis numa aula de investigação (PONTE, BROCARDO E OLIVEIRA, 2003, p.25)
\end{abstract}

3. O professor não se reconhece no currículo orientado pelos documentos oficiais.

Têm sido recorrentes, em diferentes momentos da história recente da educação brasileira, as tentativas de prescrever orientações curriculares oficiais como a versão legítima do currículo a ser executado, mesmo que os professores não reconheçam nelas ideias e propostas com as quais concordem ou não tenham se envolvido no processo de discussão e elaboração de tais orientações - em geral, capitaneadas pelos órgãos públicos de educação. (SANTOS, 2014, p.17)

4. Esse tipo de atividade "gasta" muito tempo.

5. Atividades muito abertas podem desviar o foco da aprendizagem de um conteúdo para outro menos relevante, levando ao não cumprimento do planejamento.

\title{
Sobre 4 e 5
}

A realização de investigações nas aulas de Matemática implica em menos tempo seja destinado a outras atividades. Ora, o tempo é um fator que todo professor precisa considerar na sua prática, exigindo a tomada de decisões. (PONTE, BROCARDO e OLIVEIRA, 2003)

6. A realidade da educação brasileira leva os professores a assumir uma quantidade excessiva de horas-aula, o que torna muito difícil o planejamento e a execução de atividades que necessitem de preparação. Assim, acabam optando por seguir os livros didáticos, baseando seus cursos em aulas expositivas e de exercícios. 
...e não dispondo de recursos para desenvolver as práticas de sala de aula, os professores apoiam-se quase que exclusivamente nos livros didáticos, que, muitas vezes, são de qualidade insatisfatória (BRASIL, 1998, p.22)

7. O professor toma como referência o modo como ele aprendeu e reproduz esse modelo, não levando em conta sua capacidade de criar novas situações de ensino e aprendizagem.

As hipóteses anteriores podem apontar os motivos pelos quais professores e instituições pareçam intimidados diante de novas formas de abordar o ensino de Matemática. Porém, se quisermos atribuir significado à Matemática que se ensina nas escolas, faz-se necessária a reflexão sobre os motivos que interferem na adoção de novas práticas.

Segundo Lins e Gimenez (1997, p.21) podemos considerar como fatores de resistência às mudanças:

- Visão cristalizada do currículo tradicional - Professores sofrem uma imensa pressão, institucional e social, sobre os conteúdos e a forma como deve ensinar.

- Formação tradicional do professor - O próprio professor teve, em sua vida escolar, uma formação baseada na tradição, sendo natural que veja o ensino tradicional como a forma natural de aprender e ensinar.

Mas, e quanto aos futuros professores? O que esperar dos professores que estão, atualmente, em formação?

Para responder a essas e outras questões, passamos à pesquisa com professores formados e em formação. 


\section{DESENVOLVIMENTO DA PESQUISA}

Nenhuma intervenção no processo de aprendizagem pode fazer mais diferença do que um professor bem formado, inteligente e hábil. Investir na qualidade do ensino é o que importa. A preparação do professor tem um efeito direto na realização dos alunos, pois ninguém dispõe de tanto tempo ou tem tanta influência sobre os alunos quanto os próprios professores. (ONICHIC, in BICUDO p.211)

Num primeiro momento, a busca de respostas sobre o fraco desempenho brasileiro nas avaliações nacionais e internacionais no ensino de Matemática e a aparente dificuldade de implementar mudanças, pelo menos a curto prazo, impulsionaram nossa reflexão. Porém, os autores pesquisados reforçaram a crença de que qualquer alteração passará pela formação dos professores, o que tornou obrigatório voltar os olhos para o ensino acadêmico e para os projetos de capacitação.

Teoricamente há, tanto na formação inicial quanto na formação continuada, uma preocupação metodológica e epistemológica, de refletir acerca de como os alunos lidam com o conhecimento matemático. Inúmeras vezes essa preocupação se revela na indicação de práticas que visam atribuir significados aos conceitos e procedimentos matemáticos, seja contextualizando, problematizando, investigando, argumentando ou realizando outras operações mentais que se distanciam da aprendizagem pela reprodução de modelos e repetição de operações sem a devida significação.

Porém, para além da teoria, o que se verifica é que tais práticas ainda não são comuns entre os professores. Mesmo aqueles que declaram ser a favor de um trabalho menos tradicional, parecem ter dificuldade em implementar, em seus cursos, atividades mais abertas, protagonizadas pelos 
alunos.

Parece senso comum de que deve haver alguma intervenção no sentido de tornar menos frustrante o ensino de Matemática, tanto para o aluno quanto para o professor, de modo a obter algum êxito em aproximar os significados já construídos pelos alunos dos significados em construção, propondo situações capazes de mobilizar os conhecimentos prévios e diminuindo a distância entre o aluno e seu objeto de estudo. A principal questão investigada nesse trabalho, tem foco na prática investigativa, que é uma das opções de trabalho a partir da resolução de problemas.

Faz sentido, então, conversar com alunos em formação para saber mais sobre seu grau de confiança com as novas práticas pedagógicas (em especial as aulas de investigação) e verificar se há novas perspectivas nesse sentido.

\subsection{Análise dos dados obtidos no questionário 1}

Para tentar compreender melhor as concepções dos futuros professores, foi realizada, no dia 01 de abril de 2016, uma aula envolvendo uma atividade de investigação, para os alunos da disciplina MAT0450 "Seminários de Resolução de Problemas", do curso de Licenciatura em Matemática da Universidade de São Paulo sobre o tema pesquisado.

A dinâmica da aula foi organizada em 4 etapas e durou, no total, 1 h40.

1a etapa: Questionário prévio (sondagem) para traçar o perfil e verificar como os alunos da disciplina situam a prática investigativa no universo de suas atividades como futuros professores de Matemática (anexo 1), 2aㅡ etapa: Atividade de investigação com frações,

3 etapa: Questionário sobre as impressões dos alunos e a aplicabilidade da atividade proposta (anexos 2 e 3), 4aㅡ etapa: Fechamento, discussão da atividade.

Observamos que, apesar de 56 alunos estarem presentes, nem todos responderam a todas as questões, alguns porque se estenderam muito na 
realização da atividade proposta e na discussão da tarefa, outros porque chegaram quando a sondagem já havia sido aplicada e foram direto para a segunda etapa. Não consideramos isso um problema, visto que a grande maioria mostrou-se verdadeiramente envolvida no processo.

É importante salientar que não foi feito nenhum tipo de preparação para a atividade, nem houve qualquer tipo de esclarecimento sobre o que é uma atividade de investigação.

Os alunos, obviamente, foram convidados a responder a pesquisa e informados que se tratava de um trabalho de Mestrado Profissional que estuda a "A investigação nas aulas de Matemática"6. Também foi combinado que suas identidades seriam preservadas, pois isso não era relevante para a pesquisa. Desde o início, todos mostraram-se absolutamente solícitos, com muita disponibilidade para a realização da tarefa, o que, certamente, contribuiu para a qualidade e a confiabilidade da pesquisa. $^{6}$

\section{$1^{a}$ etapa: Identificação e conhecimentos prévios dos alunos de MAT0450}

Dos 51 alunos que responderam a primeira parte do questionário, 30 nunca atuaram como professores e, dos outros 21 que já trabalham, seja na rede particular ou pública de ensino, apenas 15 afirmaram que pretendem seguir a carreira docente depois de formados. Abaixo, as questões, como foram apresentadas, e os resultados da pesquisa.

\section{Questão 1}

Você trabalha ou já trabalhou como professor?

( ) Sim, na rede pública

( ) Sim, em escola particular

\footnotetext{
${ }^{6}$ Questionário 1, em anexo
} 
( ) Nunca trabalhei como professor em escola

Questão 2

Você pretende exercer a profissão de professor?

( ) $\operatorname{Sim}$

( ) Não

( ) Ainda não me decidi

\begin{tabular}{|l|c|l|c|}
\hline \multicolumn{2}{|l|}{ TRABALHA OU JÁ TRABALHOU } & $\begin{array}{l}\text { PRETENDE } \\
\text { COMO PROFESSOR? }\end{array}$ & PROFISSÃO? \\
\hline \multirow{3}{*}{ SIM } & \multirow{3}{*}{21} & SIM & 15 \\
\cline { 3 - 4 } & & NÃO & \\
\cline { 3 - 4 } & & INDECISO & 6 \\
\hline \multirow{3}{*}{ NÃO/NUNCA } & \multirow{2}{*}{30} & SIM & 20 \\
\cline { 3 - 4 } & & NÃO & 10 \\
\cline { 3 - 4 } & & INDECISO & \\
\hline
\end{tabular}

Na questão 3, abaixo, foi apresentada uma lista de práticas e estratégias de aula que podem ser adotadas pelos professores na sua atuação profissional, entre elas as atividades de investigação. Nosso objetivo, com essa questão era de verificar quantos dos entrevistados escolheriam as atividades de investigação como uma de suas opções de atuação junto a seus alunos. Como não havia um número mínimo ou máximo de escolhas, era esperado que os alunos de MAT0450 pesquisados marcassem as opções que Ihes parecessem factíveis. 
Você se sente qualificado para atuar junto aos seus alunos aplicando quais das práticas abaixo?

\begin{tabular}{|c|c|c|c|c|}
\hline $\begin{array}{l}\text { ( }) \\
\text { Verificação e } \\
\text { aplicação de } \\
\text { propriedades } \\
\text { matemáticas }\end{array}$ & $\begin{array}{l}( \\
\text { Exercícios }\end{array}$ & $\begin{array}{l}\text { ( ) Leitura e } \\
\text { interpretação } \\
\text { de textos } \\
\text { matemáticos }\end{array}$ & $\begin{array}{l}\text { ( }) \\
\text { Discussões em } \\
\text { grupos }\end{array}$ & $\begin{array}{l}\text { ( ) } \\
\text { Comunicação } \\
\text { de ideias } \\
\text { matemáticas }\end{array}$ \\
\hline $\begin{array}{l}(\text { ) } \\
\text { Atividades de } \\
\text { investigação }\end{array}$ & $\begin{array}{l}\text { ( ) Provas } \\
\text { individuais } \\
\text { escritas }\end{array}$ & $\begin{array}{l}(\quad) \text { Aulas } \\
\text { expositivas }\end{array}$ & $\begin{array}{l}\text { ( ) Treino } \\
\text { dos algoritmos } \\
\text { e das técnicas } \\
\text { de cálculo }\end{array}$ & $\begin{array}{l}\text { ( ) Questões } \\
\text { que envolvem } \\
\text { argumentação e } \\
\text { justificativas }\end{array}$ \\
\hline $\begin{array}{l}( \\
\text { Atividades } \\
\text { experimentais } \\
\text { e jogos }\end{array}$ & $\begin{array}{l}\text { ( ) Cálculo } \\
\text { mental }\end{array}$ & $\begin{array}{ll} & \\
\text { Resolução de } \\
\text { problemas }\end{array}$ & $\begin{array}{l}(\quad) \text { Uso de } \\
\text { recursos } \\
\text { multimídia }\end{array}$ & $\begin{array}{lr}( & \\
\text { Estratégias } & \text { de } \\
\text { revisão } & \text { e } \\
\text { análise } & \text { de } \\
\text { erros. } & \end{array}$ \\
\hline
\end{tabular}

Enquanto resolver problemas é algo que praticamente todos os pesquisados se sentem qualificados para fazer com seus alunos, usar atividades de investigação parece ser uma tarefa para a qual quase metade deles não se sente preparada.

Do total dos alunos que responderam o questionário, apenas dois escreveram a palavra DÚVIDA no quadro referente às atividades de investigação. Um deles é ingressante no curso de Licenciatura, tendo cursado o bacharelado em Matemática anteriormente.

Dos alunos que nunca trabalharam como professor, um terço (10 de 30) afirmou que sentir-se preparado para conduzir atividades de investigação, enquanto, dentre os que já trabalham, repetiu-se a proporção, pois 7 de 21 pesquisados marcaram essa opção. Para esse item, a experiência profissional foi indiferente. 
Em contrapartida, do total de entrevistados, cerca de $80 \%$ declaram-se preparados para utilizar a resolução de problemas e $70 \%$ pretendem utilizar, em suas aulas, atividades que envolvem argumentação e justificativas. Os resultados estão representados na tabela e no gráfico a seguir.

\begin{tabular}{|c|c|c|c|c|}
\hline TAREFA & DESCRIÇÃO DA TAREFA & $\begin{array}{c}\text { NUNCA } \\
\text { TRABALHARAM } \\
\text { COMO PROFESSOR }\end{array}$ & $\begin{array}{l}\text { TRABALHAM OU } \\
\text { TRABALHARAM }\end{array}$ & TOTAL \\
\hline A & $\begin{array}{l}\text { Verificação e aplicação de propriedades } \\
\text { matemáticas }\end{array}$ & 24 & 17 & 41 \\
\hline B & Exercícios & 27 & 19 & 46 \\
\hline $\mathrm{C}$ & Leitura e interpretação de textos matemáticos & 20 & 17 & 37 \\
\hline $\mathrm{D}$ & Discussão em grupos & 19 & 17 & 36 \\
\hline $\mathrm{E}$ & Apresentação para os colegas & 16 & 14 & 30 \\
\hline $\mathrm{F}$ & Atividades de investigação & 10 & 7 & 17 \\
\hline G & Provas individuais escritas & 20 & 17 & 37 \\
\hline $\mathrm{H}$ & Aulas expositivas & 22 & 17 & 39 \\
\hline 1 & Treino de algoritmos e das técnicas de cálculo & 17 & 18 & 35 \\
\hline $\mathrm{J}$ & $\begin{array}{l}\text { Questões que envolvem argumentação e } \\
\text { justificativas }\end{array}$ & 17 & 18 & 35 \\
\hline K & Atividades experimentais e jogos & 20 & 15 & 35 \\
\hline $\mathrm{L}$ & Cálculo mental & 16 & 12 & 28 \\
\hline M & Resolução de problemas & 24 & 16 & 40 \\
\hline $\mathrm{N}$ & Uso de recursos multimídia & 13 & 7 & 20 \\
\hline $\mathrm{O}$ & Estratégias de revisão e análise do de erros & 12 & 9 & 21 \\
\hline
\end{tabular}




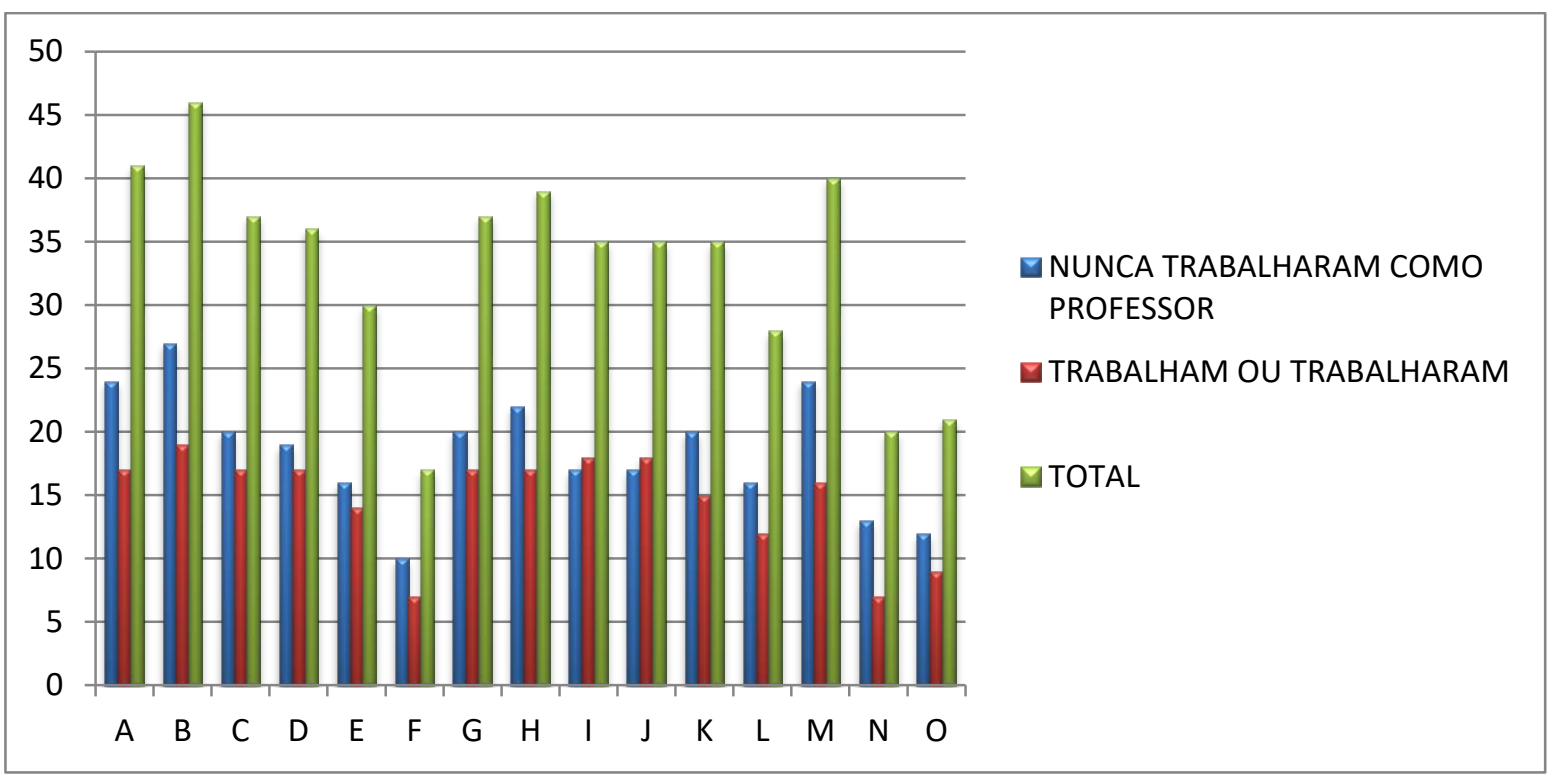

Gostaríamos ainda, a partir dos dados obtidos, de chamar a atenção para três fatos:

1) Foi com surpresa que observamos que o uso de recursos multimídia não é tão confortável para essa geração quanto se poderia supor. Alguns dos entrevistados marcaram todas as práticas, menos os recursos multimídia. Vivemos numa sociedade impregnada de tecnologia, pessoas usam seus celulares e smartphones com grande desenvoltura. Mesmo que os entrevistados tenham interpretado como recursos multimídia apenas o computador, surpreende que menos da metade dos alunos de Licenciatura pesquisados diz sentir-se qualificada para usar esses recursos em suas aulas.

2) Os itens mais escolhidos (aulas expositivas, exercícios, verificação e aplicação de propriedades matemáticas e resolução de problemas) apontam para uma prática mais tradicional. Ainda que o item resolução de problemas tenha uma grande aceitação, isso não garante que os professores sintam-se preparados para trabalhar com diferentes tipos de problemas, como aqueles que envolvem análise do erro, ou 
investigação, por exemplo, nem que darão a esses problemas o devido lugar ${ }^{7}$ em seus planejamentos.

3) Em contrapartida, parece haver uma boa aceitação de atividades que envolvem argumentação, discussão em grupo, apresentação dos alunos. Isso aponta para uma disponibilidade do professor para dar aos alunos a possibilidade comunicativa necessária para o desenvolvimento do protagonismo necessário para o desenvolvimento das atividades aqui propostas.

\section{2a etapa: Vivenciar uma Atividade de Investigação}

O problema a seguir foi apresentado por Ponte no IV SIPEMAT Simpósio Internacional de Pesquisa em Educação Matemática, ocorrido em Ilhéus/BA, em junho de 2015. Adaptações mínimas foram feitas para adequar a linguagem original em português original, de Portugal, para o português dos brasileiros:

Você está recebendo uma tira de papel azul. Seu comprimento representa $3 / 4$ de certa quantidade. Use as outras tiras para representar as seguintes frações (todas relativas à mesma quantidade):
a) $2 / 3$ do total
b) $5 / 8$ do total
c) $3 / 2$ do total
d) $2 / 5$ do total

\footnotetext{
${ }^{7}$ Nos referimos, aqui, ao uso de problemas como apontado no item 4.4 desta dissertação.
} 
A atividade foi realizada em trios ou quartetos e o material recebido pelos participantes foi:

- 1 tira de papel azul:

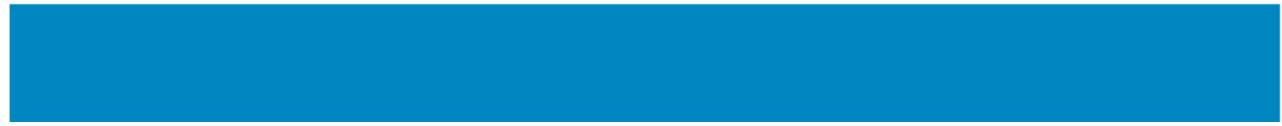

- Várias tiras de papel A3 cortado em tiras mais longas que a tira azul, porém, com a mesma largura.

Aos alunos do curso de Licenciatura foi pedido que tentassem imaginar quais recursos teria um aluno ingressante no Ensino Fundamental II para enfrentar esse problema. Isso gerou uma discussão bastante interessante sobre o repertório matemático dos alunos nessa faixa etária. A maioria dos grupos concordou que a resolução do problema deveria ser puramente aritmética, o que também constituiu mais um desafio para os participantes, acostumados ao uso de recursos essencialmente algébricos para a resolução de seus problemas.

Após o estranhamento inicial, principalmente sobre a falta de regras e orientações mais detalhadas sobre os procedimentos de realização, os grupos "mergulharam" no trabalho.

Apesar de a grande maioria dos grupos ter recorrido às dobraduras, houve quem medisse com a régua e mesmo os que tentassem usar recursos algébricos. Ficou evidente que a falta de uma orientação mais específica sobre o "como fazer" foi um agente perturbador para alguns grupos.

Foi muito interessante observar como cada grupo lidou com a situação, dobrando, colando, cortando, medindo (com régua ou com molde criado pelo grupo), emendando o papel. Alguns grupos, que usaram frações equivalentes, relataram a dificuldade com a limitação física do material, pois dobrar o papel em 12 partes, por exemplo, gerava uma espessura que impossibilitava qualquer conclusão confiável. 
A tira azul foi, premeditadamente, cortada com um comprimento de $14,2 \mathrm{~cm}$, para que não pudesse ser facilmente dividida por 3 ou 4 ou 5 . $O$ recurso de controlar essa variável didática foi pensado para atribuir algum grau de dificuldade para os alunos que, obviamente, já têm grande vivência com a manipulação matemática. Assim, para os grupos que tentaram medir com régua a imprecisão foi a principal dificuldade.

A maioria dos grupos acabou fazendo um molde do inteiro, ou seja, acrescentou o "um quarto" que faltava, completando os quatro quartos para obter a unidade. Na verdade, fizeram vários moldes da quantidade inteira, para depois dividir em novas partes e obter as frações pedidas.

Depois de realizar a atividade, houve um segundo questionário, onde os alunos de Licenciatura pesquisados falaram sobre a experiência de vivenciar, como aluno, a atividade de investigação proposta. Eles também responderam sobre sua formação, a respeito da importância (ou não) de trabalhar com diferentes tipos de tarefas durante a formação acadêmica, sobre seu grau de apreço pela atividade e sua disponibilidade e confiança para propor atividades de investigação para seus alunos.

Seguem algumas considerações e comentários dos participantes, por questão.

\section{$3^{\mathrm{a}}$ etapa: Questionário sobre as impressões dos alunos e a aplicabilidade da atividade proposta}

\section{Questão 1}

Imagine que você tenha aplicado essa atividade para seus alunos e responda:

Que dificuldades você acha que os alunos podem encontrar para realizar a tarefa? 
As respostas mais comuns versaram sobre o fato de o aluno não conhecer 0 total e sobre o enunciado ser muito aberto, mas alguns falaram também sobre o procedimento:

"Acredito que o método de ensino usualmente escolhido pelos professores não envolve questões desse tipo. Assim, acredito que pode causar estranhamento de início"

"A falta de especificações de como realizar a tarefa pode dificultar para alunos que estão acostumados a realizar atividades mais precisas"

"Talvez um enunciado mais direto, pois quando usamos termos como certa quantidade e total podemos abrir margem para várias interpretações do problema"

"Primeiro, encontrar 4/4, segundo reconhecer fração maior que o inteiro e terceiro, conseguir dividir em 5 partes, por se tratar de um número ímpar."

"Acredito que tenham dificuldade inicial para entender como realizar a tarefa. Como transformar uma tira que representa $3 / 4$ em outra que representa 2/5 ?"

"A falta de medida (valores atribuídos à quantidade total) pode atrapalhar para alunos que sabem trabalhar apenas quando valores são fornecidos".

Questão 2

A discussão desse problema entre os alunos favorece a aprendizagem? Por quê?

Praticamente todos os entrevistados responderam sim, mas os motivos foram diversos. Do total de pessoas que responderam a essa questão, apenas 
duas acharam que discussões como a proposta podem "confundir" ou "atrapalhar". Houve quem demonstrasse uma preocupação legítima com seus alunos e com as questões atitudinais.

Durante a realização da atividade, a fala nos grupos remetia tanto aos aspectos positivos quanto à preocupação com a disciplina. Enquanto alguns falavam "meus alunos adorariam aprender assim" ou "vou fazer com meus alunos, vai ser muito bom", outros diziam, "imagina esses papeizinhos na mão dos alunos, isso não ia dar certo de jeito nenhum".

Seguem alguns relatos escritos:

"Acredito que sim, porque os alunos têm perspectivas diferentes sobre o mesmo problema."

"Acredito que quem realmente se dispuser a fazer será beneficiado com uma nova visão, porém, algumas turmas podem não se focar nesse tipo de atividade."

"Sim, pois eles podem dizer um ao outro o que pensam e com as ideias concordarem na melhor ideia entre duas, onde ambos ficam convencidos, ou até pensar numa terceira nova solução."

"Há uma construção coletiva sobre o assunto."

"Sim, mas antes é necessário um extenso e exaustivo trabalho do professor para que não haja frustração no processo de compartilhamento de ideias entre os alunos."

"Sim, diferentes modos de chegar a um mesmo saber mostra que é possível, através dos conhecimentos e da vivência de cada aluno, encontrar a forma mais confortável para chegar ao resultado. Outro fator é que entrar em contato com outras formas de resolução confere aos envolvidos maiores habilidades e opções para lidar com problemas futuros."

\section{Questão 3}

Esse não é um tipo de atividade que se encontra facilmente em livros didáticos. Diga uma característica que diferencia essa atividade das "convencionais" no ensino da relação fração/quantidade. 
Para responder essa questão, o aluno teria que levar em conta seu repertório pessoal, pois os livros didáticos, para alguns, são objetos de trabalho, mas para outros, a referência são os livros usados na sua vida escolar, como alunos, quando cursavam o ensino fundamental.

"Não ter o valor da unidade muda a referência."

"A diferença mais gritante é que a atividade pode ser feita sem um cálculo sequer. Se eu fosse aplica-la, depois iria discutir os cálculos que fizemos, mesmo que de forma " oculta"."

"O aluno tem que pensar no que representa a fração $e$ não apenas em como fazer contas com ela."

"A diferença é que não basta apenas sair fazendo contas, cabe ao aluno refletir sobre o que o problema está lhe perguntando, sair um pouco da rotina dos exercícios."

"Uma característica que diferencia essa atividade é o fato de que o aluno terá espaço para criar estratégias próprias para a resolução do problema."

"Uma diferença é a liberdade para usar as tirinhas como achar certo para chegar ao resultado, geralmente usa-se tamanhos e desenhos pré-estabelecidos."

"É uma atividade prática! Nos livros geralmente encontramos propostas teóricas. Na melhor das hipóteses encontraremos pizzas e barras de chocolate."

"Ser uma atividade prática, sem ser apenas uma representação discursiva que tem como autor o professor. É o aluno que pega e faz" 


\section{Questão 4}

Obviamente poderíamos propor uma atividade como essa só usando números, como: "Maria comprou 3/4 de quilo de carne e pagou $\mathrm{R} \$ 15,00$. Quanto pagaria por 1/2 quilo?". Cite duas vantagens e duas desvantagens que você identifica para trabalhar com o problema a partir das tiras de papel.

\begin{tabular}{|l|l|}
\hline DESVANTAGENS & VANTAGENS \\
\hline & \\
\hline & \\
\hline & \\
\hline
\end{tabular}

A intenção aqui era que o futuro professor observasse um enunciado tradicional, que poderia estar em várias obras consagradas pelo mercado do livro didático e cujo enunciado pode ser desprovido de significado para o aluno.

Afinal, quem vai ao açougue e pede $3 / 4$ de quilo de carne, na era da balança digital? Aliás, quem vai ao açougue, na era do supermercado? E, mesmo que o aluno fosse ao açougue e pedisse $3 / 4$ de quilo de carne, esse problema teria potencial para motivar os alunos? Esse é um contexto absolutamente artificial! Nesse caso, parece melhor lidar com as tiras de papel, que não guardam nenhum tipo de relação com a vida cotidiana, mas que tem, pela manipulação que possibilita, maior chance de envolver os alunos na tarefa.

Essa questão, por ser aberta, apresentou respostas diversas, que foram agrupadas. Por exemplo, frases como "pode gerar indisciplina" e "os alunos tendem a se dispersar e a disciplina pode ficar comprometida" estariam juntas no item "Favorece a indisciplina e a dispersão" não existindo aqui uma preocupação ou o compromisso com a transcrição literal da resposta dada.

Também é importante ressaltar que nem todas as respostas estão aqui elencadas. Vantagens e desvantagens com apenas uma citação não foram 
tabuladas.

É interessante observar que as desvantagens apontadas pelos atuais e futuros professores pesquisados nesta turma de Licenciatura remetem a várias das hipóteses antecipadas como motivadores da resistência de professores para o trabalho com investigação nas aulas de Matemática.

Seguem as vantagens e desvantagens apontadas por eles:

\begin{tabular}{|l|c|}
\hline \multicolumn{1}{|c|}{ DESVANTAGENS } & FREQUÊNCIA \\
\hline Não formalização / não desenvolve algoritmos & 12 \\
\hline Limitação física ( espessura do papel, precisão) & 1 \\
\hline Abordagem parcial do tema & 7 \\
\hline Favorece a indisciplina ou a dispersão & 5 \\
\hline A atividade pode ser confusa ou tediosa & 3 \\
\hline Não tem relação com o cotidiano escolar & 10 \\
\hline Não faz relação com números racionais & 2 \\
\hline Abstrato / nível alto de dificuldade & 3 \\
\hline Dificuldade na gestão/ leva muito tempo & 8 \\
\hline
\end{tabular}




\section{DESVANTAGENS}

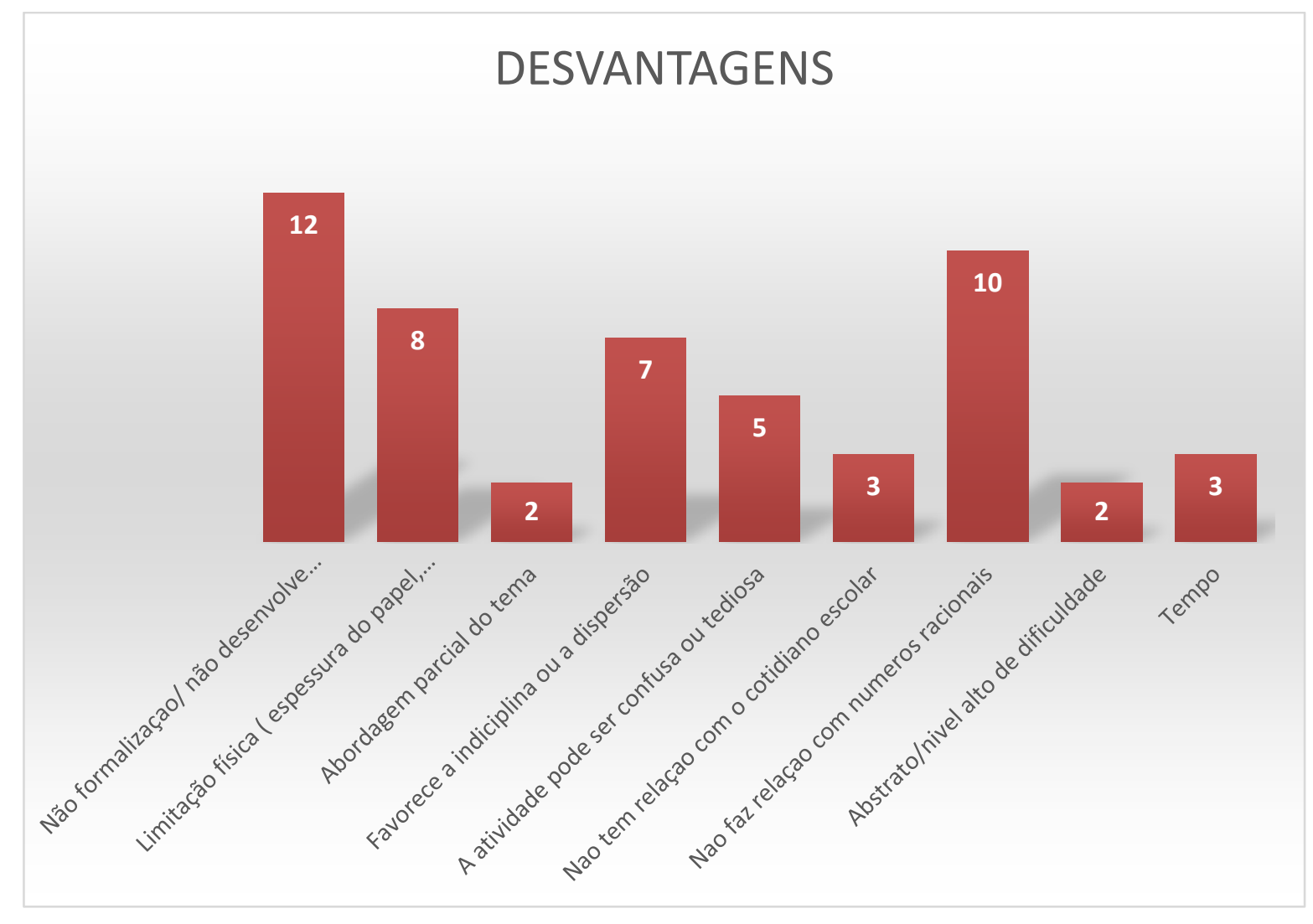

Quanto às VANTAGENS da atividade também não houve grandes surpresas, conforme se verifica no quadro abaixo:

\begin{tabular}{|l|c|}
\hline \multicolumn{1}{|c|}{ VANTAGENS } & FREQUÊNCIA \\
\hline Relação com a geometria & 4 \\
\hline Independe de números & 4 \\
\hline Estimulam o envolvimento / motivação & 7 \\
\hline Interação entre os alunos/ participação & 10 \\
\hline Reflexão mais profunda & 5 \\
\hline Uso de material/manipulação favorece a aprendizagem & 11 \\
\hline Vizualização / compreensão do conceito & 18 \\
\hline Estímulo à criatividade e à curiosidade & 5 \\
\hline Desenvolve estratégias para problemas futuros & 6 \\
\hline Raciocínio lógico & 4 \\
\hline
\end{tabular}




\section{VANTAGENS}

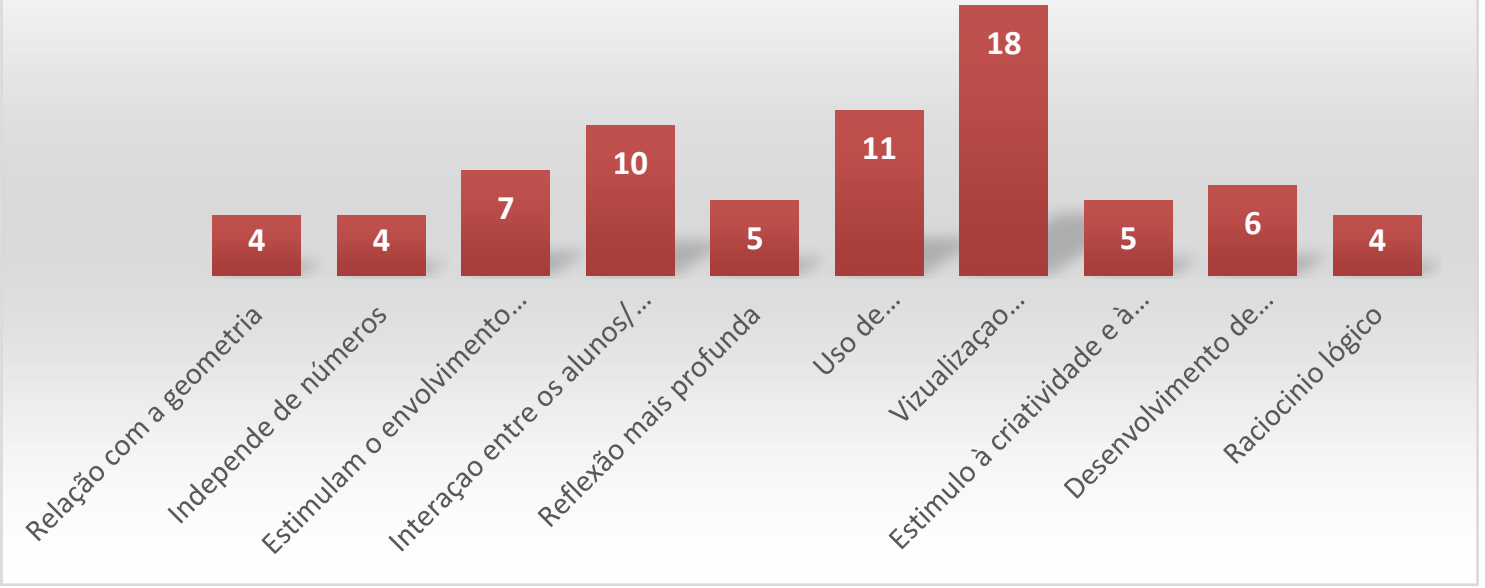

$\mathrm{Na}$ parte do questionário que investigava o curso de Licenciatura e a visão dos alunos sobre sua formação, as respostas obtidas revelaram o quanto a vivência acadêmica não contempla as atividades de investigação. Abaixo seguem algumas questões com as respectivas respostas (questionário completo em anexo)

Questão 7

$\mathrm{Na}$ atividade com as frações você foi convidado a participar como aluno. Como você avalia essa atividade?

Para essa questão houve quase uma unanimidade. Dos 51 alunos de Licenciatura, 48 afirmaram ter gostado de participar como aluno de uma atividade de investigação. As justificativas são as mais variadas "ajuda a entender a dificuldade deles", "ajuda a compreender como o aluno pensa e desenvolve o raciocínio", Nos faz refletir como melhorar nossas propostas", "tira o aluno de sua zona de conforto".

Apenas três respostas foram negativas, segue a transcrição:

"Já havia resolvido problemas similares e não apresentou nenhuma 
novidade", "Não achei a atividade didática. Acredito que tenho maneiras melhores de fazer essa proposta", "Gostei como ideia para o aluno, mas não gostei de fazer".

\section{Questão 8}

No curso de Licenciatura em Matemática você diria que realizou atividades como a descrita acima:

( ) Muitas vezes

( ) Poucas vezes

( ) Raramente

Seguem as respostas:

\begin{tabular}{|l|c|}
\hline Muitas vezes & 1 \\
\hline Poucas vezes & 19 \\
\hline Raramente & 29 \\
\hline Não soube opinar & 1 \\
\hline
\end{tabular}

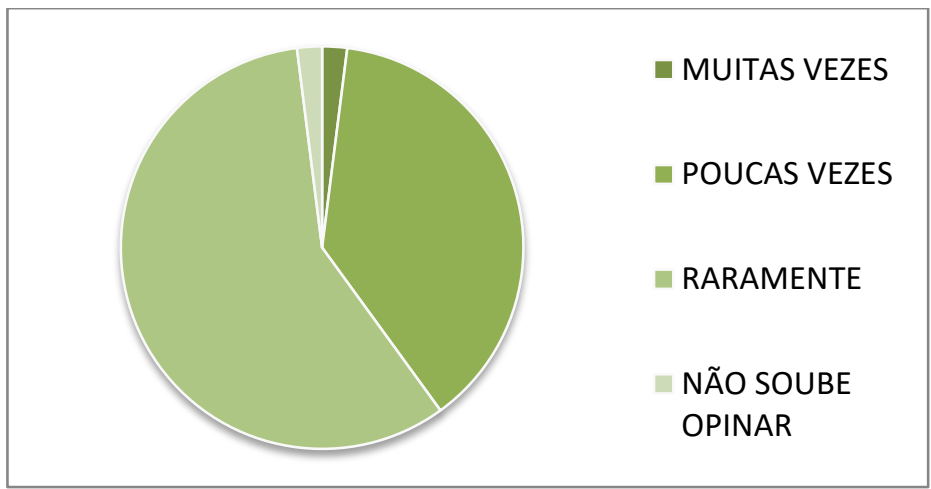

Questão 9

Você pretende incorporar à sua prática, como professor, atividades que envolvem investigação, como a que acaba de realizar? Justifique.

Apesar de terem acabado de declarar, na questão 8, sua inexperiência, mesmo aqueles que já estão no mercado de trabalho, praticamente todos os 
alunos de Licenciatura pesquisados se mostraram entusiasmados em incluir aulas de investigação em seus cursos. Apenas um dos entrevistados respondeu não, sem justificar. Outro preferiu não se posicionar, afirmando: "Honestamente, ainda não entendi o que é investigar."

Outra questão interessante foi avaliar o grau de confiança quanto à capacidade de trabalhar com os futuros alunos com atividades parecidas com a proposta. Do total, apenas dois alunos disseram não se enquadrar em nenhuma das opções. Os demais responderam segundo a distribuição a seguir:

Questão 10

Você diria que, no curso de Licenciatura, teve a oportunidade de vivenciar diferentes práticas (inclusive a investigativa) e que isso forneceu os subsídios necessários para trabalhar com atividades diversificadas em sala de aula, com seus futuros alunos?

( 10 ) Sim, sinto-me confiante para trabalhar com diferentes práticas.

( 33 ) Mais ou menos, acho que ainda precisarei de novos cursos de formação.

( 6 ) Não, acho que terei dificuldade em realizar um trabalho desse tipo.

( 2 ) Não opinaram

Seguem as respostas:

\begin{tabular}{|l|c|}
\hline Sim, sinto-me confiante para trabalhar com diferentes práticas. & 1 \\
\hline Mais ou menos, acho que ainda precisarei de novos cursos de formação. & 19 \\
\hline Não, acho que terei dificuldade em realizar um trabalho desse tipo. & 29 \\
\hline Não opinaram & 1 \\
\hline
\end{tabular}




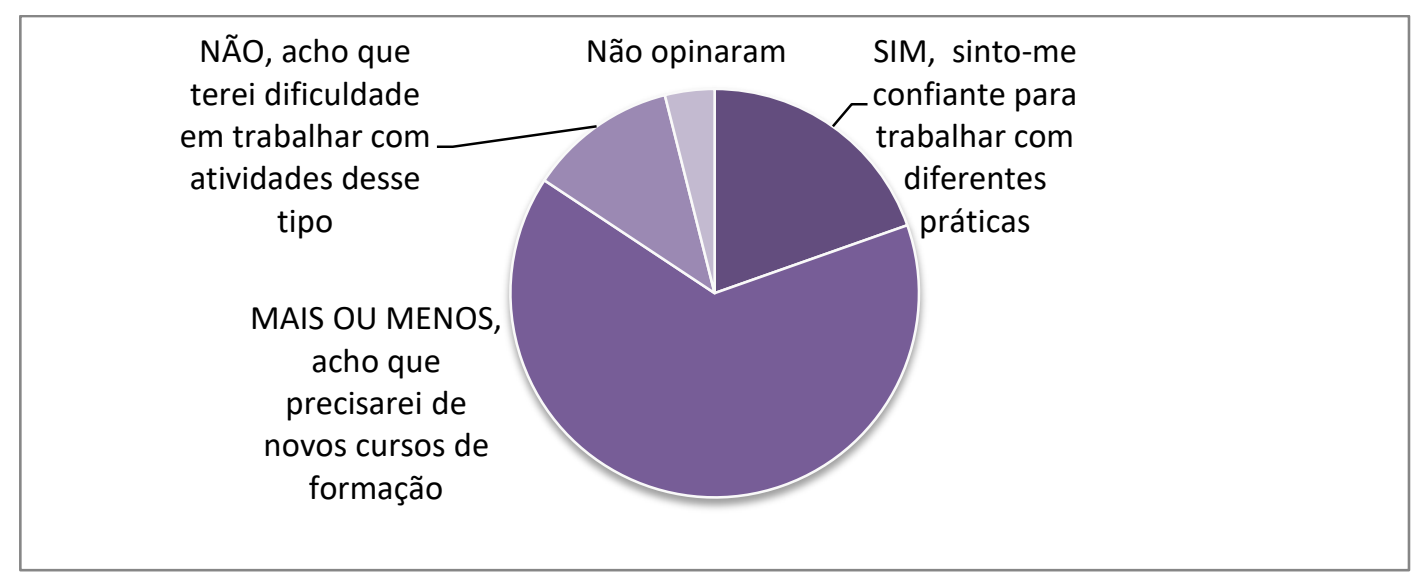

Também foi proposta uma última questão aberta, para que os alunos do curso de Licenciatura pesquisados comentassem sua percepção sobre o tipo de formação que estão tendo.

\section{Questão 11}

"Em contrapartida à simples reprodução de procedimentos e ao acúmulo de informações, educadores matemáticos apontam para a resolução de problemas como ponto de partida da atividade matemática. Essa opção traz implícita a conviç̧ão de que o conhecimento matemático ganha significado quando os alunos têm situações desafiadoras para resolver e trabalham para desenvolver estratégias de resolução". (BRASIL, 1998 p.39/40)

Você identifica, no curso de Licenciatura, uma preocupação com a formação dos professores para atuar de acordo com o que foi apontado no trecho acima? Comente.

Aqui, foi interessante perceber como os alunos pesquisados atribuem aos professores - e não ao conteúdo programático ou à estruturação do curso - a responsabilidade pelas escolhas curriculares. Em poucos casos as respostas criticaram o curso como um todo, revelando que ainda há uma expectativa que o indivíduo, não a instituição, se responsabilize por eventuais mudanças. Algumas respostas: 
"Muito pouco, temos uma matéria de resolução de Problemas, colocaram o Laboratório de Matemática e, que foi muito positivo, História da Matemática e algumas matérias da Educação, como, por exemplo, Didática. Poderíamos ter mais matérias voltadas para o ensino de Metodologia."

"Não, pois os professores, na sua maioria pesquisadores, aparentemente não se mostram preocupados em desafiar 0 aluno dessa forma e sim cumprir o conteúdo programático."

"Quando os professores têm formação na área de educação, sim, há essa preocupação. Caso contrário, é difícil."

"Sim, já tive e tenho professores preocupados com essa situação. Em geral, esses professores têm um nível de cobrança maior com seus alunos e nos deixam mais próximos do que teremos dando aula."

"Sim, pelo menos nas matérias que temos na Faculdade de Educação, há uma preocupação nesse sentido. E com certeza está presente no IME também."

"Pelo que sempre ouvi falar, essa é uma reinvindicação geral. Portanto, acredito que este é um problema que está sendo atacado recentemente e esperamos que os professores se mantenham com essa preocupação."

"Não, ainda penso que os cursos são focados em conteúdos. As matérias que mostram novas metodologias ou ferramentas para a sala de aula são optativas, então muitos alunos acabam não vendo todas as possibilidades".

\section{4aㅡ etapa: Fechamento}

Chamou atenção o grande número de participantes "ávidos" por algum tipo de generalização já na primeira atividade. Muitos dos participantes consideram que é necessário chegar a uma conclusão, ou formalizar um conteúdo, para garantir a aprendizagem. Essa discussão foi muito interessante, pois reflete uma preocupação de alguns em formatar a atividade de modo que se possa dizer "com essa atividade o aluno aprendeu isso ou aquilo", enquanto para outros parecia tranquilo que a atividade pudesse ser apenas o início do processo de construção de um novo conhecimento. 
Outro aspecto que merece ser comentado é o fato de quase $20 \%$ do grupo ter afirmado que a tarefa não tem relação com os números racionais. Não foi possível entrevistar novamente essas pessoas para entender essa afirmação. A hipótese mais forte é que as pessoas não tenham relacionado a atividade com o conteúdo números racionais da forma como é apresentado nos livros didáticos.

É nesse tipo de contexto que se revela a concepção "fossilizada" - no sentido utilizado por Lins e Gimenez (1997) - que os professores ainda têm a respeito do ensino da Aritmética e da Álgebra. É como se uma aula em que não se generaliza ou não se faz uma lista de exercícios não fosse uma boa aula. Pareceu haver, por parte dos alunos de MAT0450 pesquisados, uma expectativa de que o problema ficasse totalmente esgotado em um encontro.

Esta questão foi discutida no grupo. Ponderamos que, nem sempre, a atividade "caberá" no tempo didático de uma ou duas aulas. Também pode haver variações de tempo e até do grau de aprofundamento da discussão de uma turma para outra. Não há problema nisso, desde que o professor saiba conduzir a tarefa de modo a garantir a aprendizagem. Também não há a necessidade de esgotar o assunto. Muito pelo contrário. Uma investigação pode estar a serviço de disparar uma nova aprendizagem, sendo seguida de tarefas de outra natureza em aulas subsequentes. Apenas é preciso que o professor fique atento para que os momentos da investigação estejam garantidos. É preciso que os alunos possam compartilhar o resultado de seu trabalho e tenham a oportunidade de ouvir seus pares.

Ainda houve um pequeno grupo de alunos que observou que a atividade proposta ainda teria potencial para novas explorações. Mudando a variável didática, como um aluno sugeriu: "se pedíssemos um número primo um pouco maior, como o treze, por exemplo, o aluno precisaria de outra estratégia". Outro sugeriu que poderia ser pedido que o aluno "mostrasse um método para, sabendo três quartos de um total, determinar outras frações do mesmo total, sem usar material algum".

Discutimos brevemente, mas ficou evidente que o grupo de alunos do curso de Licenciatura pesquisado, ao se tornarem professores, teriam toda a 
condição de ao menos tentar se engajar em um projeto de inserção de práticas investigativas em seus cursos, mesmo que isso demandasse um pouco mais de pesquisa e aprofundamento sobre o tema.

\subsection{Análise dos dados obtidos no questionário 2}

Com os dados levantados pelo primeiro questionário fortalecemos algumas hipóteses, mas também criamos novas perguntas. Naquele momento, o que mais intrigava era descobrir o que desperta no professor uma predisposição à adoção de novas práticas. Nas obras pesquisadas, vimos que há uma série de obstáculos, que passam pelas condições de trabalho, pela formação, pela vontade política dos governos e instituições, mas sabemos que há algo de pessoal, há escolhas que professores fazem em função de sua experiência e daquilo que acreditam ser melhor para o desenvolvimento dos seus alunos. É o depoimento desses profissionais que procuramos, pois, afinal, qualquer mudança passa pelo engajamento dos professores.

Como descrito na Metodologia, obtivemos poucas respostas ao segundo questionário, mas elas foram preciosas do ponto de vista da pesquisa, porque são relatos de pessoas que, supostamente, acreditam que as atividades de investigação devem ter lugar nos planejamentos, que já incluem tarefas desse tipo em sua prática pedagógica.

Mesmo conscientes de que esse grupo não representa a totalidade dos professores em exercício e assumindo que podemos estar lidando com um grupo de "entusiastas" das atividades de investigação, o conteúdo dessa pesquisa foi levado em conta, e serviu para formular as questões do $3^{\circ}$ questionário. Além disso, as conclusões deste trabalho referem-se aos professores em formação, sendo assim, não serão influenciadas por esse pequeno grupo de professores.

Segue a transcrição das respostas obtidas para algumas questões ${ }^{8}$ :

\footnotetext{
${ }^{8}$ Questionário 2, em anexo
} 


\section{Questão 1}

Você já conhece ou usa atividades de investigação na sua prática? Fale brevemente sobre sua experiência.

Sim, em minha opinião, atividades diferenciadas na escola tradicional de educação básica são sempre bem-vindas. Durante a minha carreira profissional, fui percebendo gradualmente a importância de atividades desse tipo, e busquei participar de cursos e projetos dessa natureza.

Sempre que posso e que consigo uso na sala de aula, mas tudo aqui é muito lento, trabalho para a prefeitura da cidade onde temos uma proposta diferente. Gosto quando consigo um tempo e posso trabalhar investigações com os alunos. Uns gostam muito outros não demonstram tanto interesse.

Conheço e uso. Acho essencial o trabalho com investigação, principalmente ao lançar um novo conteúdo ou até mesmo em momentos de sistematização. Também pode ser usado quando queremos aprofundar algum conteúdo com atividades em grupo.

\section{Questão 2}

Já sendo experiente ou mesmo que nunca tenha trabalhado com atividades de investigação, classifique de 0 a 3 seu grau de afinidade com esse tipo de proposta (Use 0 para não me identifico e 3 para me identifico totalmente). Comente sua opção de resposta.

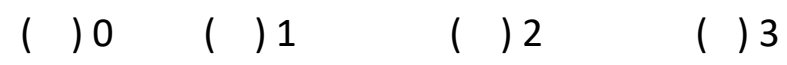

Classificação 3 - Julgo importante e procuro fazer ao máximo possível, mesmo que não consiga em $100 \%$ das vezes. Para mim, é parte de uma metodologia que faz sentido, para alunos e para o processo ensinoaprendizagem, como um todo.

Classificação 3 - A investigação dá autonomia ao aluno, torna-o agente de seu aprendizado. E isto modifica a relação do aluno com a sala de aula, com o conhecimento. A investigação também modifica a relação do aluno com o erro que passa a ser encarado como uma etapa da aprendizagem. 
Ao investigar é natural que a primeira conclusão nem sempre seja correta obrigando o aluno a voltar, rever e refazer trajetórias.

\section{Questão 7}

Comente se sua formação acadêmica foi favorável ou desfavorável para o trabalho com atividades de investigação.

"Minha formação inicial não se preocupou com esse aspecto. Poucos aspectos relacionados à prática docente foram abordados na minha formação. Minha experiência com esse tipo de proposta vem dos cursos de formação continuada e da experiência com colegas professores."

" A minha formação acadêmica foi desfavorável à realização de atividades investigativas, pois apesar do curso ser de Licenciatura, era sempre uma relação tradicional entre professor e aluno."

\section{Questão 8}

1. Comente se suas condições de trabalho são favoráveis ou desfavoráveis para o trabalho com atividades de investigação.

"Sim. Conto com um número adequado de alunos por classe, um estagiário em tempo integral acompanhando as aulas e apoio da instituição para aplicação desse tipo de proposta."

"Apesar das minhas condições de trabalho ser desfavoráveis à realização de atividades investigativas, com um número excessivo de alunos por sala (35 no EFAF) e (40 no EM), o que dificulta realização de atividades diferentes que proporcionam mais atenção e orientação do professor, também há uma precarização de recursos didáticos, como materiais (cópias) nas escolas públicas, e por fim, nota-se um pré-julgamento entre o ensinar, aprender e disciplina. Então, procuro trabalhar com essas atividades ou outras diferenciadas quando são orientados em livros ou apostilas ou quando participo de algum projeto onde tenho ajuda de alunos estagiários."

“Totalmente favoráveis! É pelo que prezamos onde trabalho" 


\subsection{Análise dos dados obtidos no questionário 3}

Conforme descrito na Metodologia, no dia 15/08/2017, foi aplicado um questionário para os 24 alunos presentes na aula de MAT 1500 - Projetos de Estágio.

A intenção desse instrumento era verificar a aceitação daquele grupo e o grau de confiança que teriam para trabalhar atividades de investigação com seus alunos.

Para isso, foi feita uma pesquisa em três etapas:

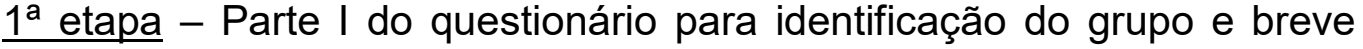
apresentação do tema, abordando:

- O que é uma atividade de investigação e quais suas características,

- $\quad$ Como é a dinâmica de uma aula de investigação.

\section{$\underline{2^{\mathrm{a}} \text { etapa }}$ - Vivência}

Os alunos da turma realizam a atividade seguindo os mesmos passos realizados com alunos de sétimo ano do Ensino Fundamental de uma escola particular de Santana de Parnaíba/SP, respeitando, inclusive, as restrições de repertório matemático dos alunos, com recursos puramente aritméticos. Durante a atividade, foi feito um relato do que aconteceu no sétimo ano à medida que os alunos de MAT 1500 faziam suas próprias tentativas e descobertas.

$\underline{3^{a} \text { etapa }}$ - Parte II do questionário

Os alunos pesquisados responderam individualmente a parte II do 
questionário levando em conta a atividade vivenciada, sua experiência profissional e sua formação.

Os depoimentos utilizados foram retirados do questionário 2 , descrito no item 5.2 desta dissertação.

Seguem os dados obtidos a partir dos 24 questionários recebidos:

PARTE I - Identificação dos entrevistados e primeira aproximação com o tema.

\section{Questão 1}

Você trabalha ou já trabalhou como professor?

Respostas: $\quad$ Sim, na rede pública -8

Sim, em escola particular - 4

Nunca trabalhei como professor -8

Afirmaram trabalhar tanto na escola pública quanto na particular - 4

\section{Questão 2}

Você pretende exercer a profissão de professor

Respostas:

Sim - 19 (sendo 12 que já exercem e 7 que ainda não são professores)

Não - Apenas 1

Ainda não me decidi - 4 (sendo 3 que já exercem e 1 que ainda não trabalha como professor) 
Você já tinha ouvido falar, estudado, pesquisado sobre Investigação Matemática?

Respostas: $\operatorname{Sim}-15$

$$
\text { Não }-9
$$

Vale ressaltar que na resposta para essa questão a proporção dos que já sabiam algo sobre as atividades de investigação foi a mesma entre os que já trabalham e os que nunca exerceram a atividade de professor. Ou seja, para essa amostra, o fato de estar ou não inserido em um ambiente escolar não foi relevante.

Questão 4

O termo "Atividade de Investigação" refere-se ao trabalho do Prof. Dr. João Pedro da Ponte, da Universidade de Lisboa, que afirma: "Investigar é procurar conhecer o que não se sabe".

Segundo ele, um problema de investigação não precisa ser, necessariamente difícil. "Trata-se de uma questão mais aberta - a questão não está bem definida no início, cabendo a quem investiga um papel fundamental na sua definição"(p.23)

Um exemplo poderia ser: O QUE SE PODE GARANTIR SOBRE OS EIXOS DE SIMETRIA NOS POLÍGONOS REGULARES?

Na sua opinião, esse tipo de problema tem potencial para promover boas situações de aprendizagem?

Respostas: $\operatorname{Sim}-20$

$$
\text { Não - } 0
$$

Apresentaram restrições - 4 alunos

As restrições são legítimas. Entre elas, alguns comentários merecem destaque, seja pela argumentação ou por revelarem receios e concepções dos 
participantes. Um deles responde: "Acho que funciona com um número restrito de alunos. Em geral, quando uma questão é bem definida, o aluno pode se preocupar mais com o professor espera que o aluno responda do que em investigar". Outro afirma: "Fico bem na dúvida, pois dá sim para investigar em Geometria, mas ao mesmo tempo, muitos resultados podem enganar e embaralhar a mente dos alunos". Há ainda quem vincule a aprendizagem ao interesse pelo tema trabalhado: "Caso o aluno tenha interesse, é possível que haja boas discussões sobre o assunto".

Mas, de modo geral, os entrevistados parecem enxergar potencial nas atividades de investigação para promover boas situações de aprendizagem. Seguem alguns trechos que corroboram essa ideia: "Sim, porque o aluno conseguirá compreender melhor sobre o tema, analisando-o de fato", ou "Sim, pois muitos conceitos serão abordados antes de chegar à resposta "oficial" do problema".

\section{Questão 5}

Ponte questiona, na introdução de seu livro "Investigações Matemáticas na Sala de Aula": "Pode o trabalho de investigação dos matemáticos servir de inspiração para o trabalho a realizar por professores e alunos nas aulas de Matemática"? Importa saber se está ao alcance dos alunos investigar questões matemáticas e de que forma isso pode contribuir para sua aprendizagem. Importa também saber que competências necessitam os professores para promover esse tipo de trabalho em suas aulas e que condições são necessárias para que isso aconteça".

Responda:

Você acha que o trabalho dos matemáticos (formular questões, conjecturas, testar, justificar, analisar) pode ser reproduzido com os alunos? Comente.

Respostas: $\operatorname{Sim}-19$

Não - 1

Outras respostas -4 
Alguns argumentos dos entrevistados que responderam sim mostram grande afinidade com a proposta, ressaltando que é preciso entender e respeitar as possibilidades de cada faixa etária. Também surgiram colocações ligadas à motivação e à criação de um ambiente propício, como "Não acho que reproduzido seja um bom termo, mas sim desenvolvido..." ou "... acho que esse processo reforça a possibilidade que eles têm. Para mim, isso faz com que acreditem mais em si." E, ainda, " uma justificativa deve vir à tona quando surge da necessidade, colocando o aluno instigado a entender o porquê de cada coisa". "... e que os alunos estejam adaptados a situações de seu cotidiano com incentivo para pesquisar e formular questões."

Há ainda um grupo mais contido, que enxerga potencial pedagógico quando o aluno reproduz o trabalho de investigação dos matemáticos, mas coloca restrições, como em "Com uma dose de bom senso sim, em turmas mais adiantadas. Em anos iniciais, o formalismo e o jargão atrapalham, bem como a notação esdrúxula."

Um dos entrevistados destaca o papel do professor: "Sim, basta 0 professor ser o mediador e induzi-los/ensiná-los a criar o hábito de pesquisa, transformando-os em pessoas autônomas."

Apesar de apenas um entrevistado ter respondido não, passamos a transcrever a sua resposta, pois a argumentação aponta para a necessidade de mudança no sistema atual e poderia ser encarada como uma resposta afirmativa, com restrições: "Acho que não. Embora em turmas com menos de dez alunos isso até pareça ser possível. O atual método de educação (conteudista) não abre espaço para esse tipo de trabalho. Atualmente é notável uma preocupação maior com a nota e a aprovação do que com o que se está aprendendo".

$\underline{\text { PARTE II - Avaliação da Atividade }}{ }^{9}$

\footnotetext{
${ }^{9}$ Questionário em anexo
} 


\section{Questão 1}

Depois de ter vivenciado uma atividade de investigação e ouvido o relato sobre o desempenho dos alunos, responda:

a. Que dificuldades você imagina que um professor pode enfrentar com esse tipo de proposta em sala de aula?

b. Que dificuldade esse tipo de proposta pode trazer para os alunos?

Para essa questão houve uma grande variedade de respostas. Como os entrevistados podiam apontar mais de uma dificuldade, há um grande número de respostas. Abaixo, elas são apresentadas pelo grau de relevância dentro do grupo. As respostas que só apareceram uma vez foram agrupadas. O número entre parênteses aponta a frequência da resposta.

\section{DIFICULDADES ENFRENTADAS PELOS PROFESSORES}

- (7) Gestão da classe e da aula

- (6) Desinteresse e resistência dos alunos

- (3) Tempo de planejamento

- (3) Controle da turma/disciplina

- (3) Administrar alunos com dificuldades em assuntos básicos

- (3) Criar ou pesquisar boas propostas

- (2) Surgirem questões que o professor não antecipou

- (1) Quantidade de alunos por turma, ensinar linguagem matemática, justificar a validade da proposta.

\section{DIFICULDADES ENFRENTADAS PELOS ALUNOS}

- (6) Frustração/ falta de confiança

- (5) Sair do convencional, habitual

- (4) Manipulação matemática

- (4) Dispersão

- (3) Comunicação (comunicar ideias com clareza) 
- (3) O aluno pode ficar confuso

- (1) Falta de conceitos básicos, dificuldade em apropriar-se da proposta.

\section{Questão 2}

Veja o depoimento de uma professora sobre sua prática com atividades de investigação:

"Penso que as relações mentais que o desenvolvimento de atividades investigativas favorece a aprendizagem significativa, dando ao aluno autonomia para estabelecer relações matemáticas importantes e estruturantes, que pudessem ficar fragilizadas se esse aluno fosse submetido apenas à realização de atividades tradicionais, mecânicas, vazias de sentido."

Classifique de 0 a 5 seu nível de concordância com a professora ( 0 para não concordo e 5 para concordo plenamente)

Para essa questão, como não foi proposto nenhum tipo de justificativa, os entrevistados simplesmente quantificaram seu grau de concordância com o depoimento citado. Seguem os resultados com as quantidades de respostas entre parênteses:
( 0 ) 0
$\left(\begin{array}{ll}0 & ) \\ 1\end{array}\right.$
$(0) 2$
$(1) 3$
( 6 ) 4

$15) 5$

Obs: Dois entrevistados não responderam.

Questão 3

Sobre a questão "Suas condições de trabalho são favoráveis ou desfavoráveis para trabalhar com investigações?", uma professora da escola pública respondeu: "OS dois, dependemos muito dos gestores da escola". 
Quais as condições de trabalho, na sua opinião, que favorecem a implementação de atividades diferenciadas nas aulas de Matemática? O professor deve ter autonomia para escolher?

Os entrevistados foram unânimes em responder que o professor deve, sim, ter autonomia para escolher inserir atividades diferenciadas em suas aulas. Motivados pela questão, apontam os fatores que favoreceriam essa implementação. Segue a síntese das respostas mais recorrentes, com a frequência entre parênteses, e alguns comentários sobre as condições favoráveis à adoção de atividades diferenciadas, inclusive o trabalho com investigação, nas aulas de Matemática:

- (7) Estrutura física adequada - Instalações, mobiliário, equipamentos, limpeza;

- ( 5 ) Perfil favorável da turma e da escola;

- ( 4 ) Menor pressão por resultados e cumprimento de metas;

- ( 4 ) Apoio da gestão da escola e dos colegas;

- ( 3 ) Tempo para elaboração e aplicação das atividades;

- ( 2 ) Qualificação do professor.

Comentários dos entrevistados:

"Cumprir calendário não é ensinar"

"Encarar a gestão e afrontar é um risco a correr"

"É possível investigar com o mínimo de recursos"

"O sistema sempre conduz ao método tradicional"

Questão 4

Você acha que, mesmo em instituições mais fechadas, é possível criar condições para o desenvolvimento de atividades menos tradicionais (como listas de exercícios, atividades individuais, etc)? 
Para essa questão, os três professores que trabalham com sistemas apostilados responderam que só seria possível se houvesse um interesse da instituição, em atividades pontuais.

Seis pesquisados não responderam.

Do grupo que respondeu sim, destacamos as respostas mais frequentes:

- (4) Depende da vontade e da perseverança do professor;

- (4) Inserção deve ser gradual, em situações pontuais;

- (3) É importante inovar;

- (3) O feedback é importante.

Questão 5

A questão 5 traz à tona a questão atitudinal:

O trabalho com problemas de investigação pressupõe envolvimento do aluno, ambiente colaborativo e interação respeitosa. Você acha que essas condições estão garantidas nas escolas brasileiras? Comente.

Seguem as respostas:

Sim, essas condições estão garantidas - 0

Não, as condições não estão garantidas - 14

Nem sempre as condições estão garantidas -5

Não responderam - 5

Entre os comentários mais frequentes estão a falta de estrutura familiar, a cultura escolar desfavorável, questões atitudinais comuns nas escolas, desrespeito pelos colegas e pelo professor. Porém, os entrevistados mostramse dispostos a investir na construção de um ambiente favorável à pratica investigativa, dizem que o respeito mútuo é algo a ser trabalhado, que é preciso insistir e que é importante que um contrato didático esteja estabelecido para que o trabalho possa fluir. 
Apresentamos alguns desses comentários:

"Quanto mais insistirmos em atividades diferenciadas, mais os alunos colaborarão para atingirmos essas condições."

"É preciso instaurar um ambiente respeitoso e colaborativo nas escolas públicas."

"De fato, o respeito mútuo deve ser trabalhado, mas acredito que os temas possam ser trabalhados com o auxílio do professor responsável pela classe."

Questão 6

Veja como um professor respondeu à questão "Comente se sua formação acadêmica foi favorável ou desfavorável para o trabalho com atividades de investigação."

Foi favorável, mas poderia ter sido ainda melhor. Vejo que boa parte das coisas que aprendi foram na prática, tendo que ser professor, e não aluno da graduação. Boa parte aprendemos apenas quando lecionamos, e isso é natural, principalmente por ter que investigar os "porquês". Mas, a graduação poderia ter contribuído um pouco mais, para além de importantes reflexões que me foram propostas.

E você?

Sobre sua formação acadêmica, classifique de 0 a 5 seu nível de conforto para trabalhar com atividades diferenciadas, como as de investigação. (Use 0 para não me sinto preparado e 5 para estou plenamente confiante)

Seguem as respostas, com a frequência entre parênteses:
( 0 ) 0
( 2 ) 1
( 1 ) 2
( 6 ) 3
( 4 ) 4

) 5

Obs: 6 pessoas não responderam essa questão. 


\section{Questão 7}

Você estaria disposto a inserir em sua prática atividades de investigação? Comente

A resposta sim predominou, os entrevistados comentaram principalmente sobre a necessidade de mudanças no ensino atual. Mostraram preocupação com a relação do aluno com a aprendizagem significativa. Também foi frequente, com cinco citações, a preocupação com a formação e a qualificação para trabalhar as atividades de investigação com seus alunos.

Segue a transcrição de algumas respostas:

"Sim, pois tanto ajudam na formação dos alunos como na nossa formação."

"Sim, sinto que na minha formação faltou um enfoque na estruturação de atividades que envolvam o aluno e o torne autônomo. Certamente seriam atividades que eu implementaria pelo fato de propor maior interação entre os alunos e entre os alunos e os conteúdos em si."

"Com certeza, eu quero tirar essa ideia que os alunos têm de que Matemática é chata. Quero apresentar atividades que causem motivação e satisfação e que façam sentido para os alunos."

"Com certeza estaria. Acredito que os alunos chegarem aos mesmos resultados que outros antes deles chegaram faz com que acreditem em si. Talvez isso ajude a quebrar o tabu de que Matemática é só para os inteligentes." 


\section{CONCLUSÕES}

Entretanto, logo que cessam os efeitos da Licenciatura, ou mesmo antes disso, há dramáticas evidências de que as concepções e práticas dos professores são rapidamente absorvidas pela ideologia escolar tradicional e a mudança é anulada (BORKO et al., 1992; ENSOR, 1998; SCHMIDT \& DUNCAN, 1998, apud BALDINO, in BICUDO 1999, p. 224)

A proposta de verificar as concepções de alunos de Licenciatura a respeito do trabalho com atividades de investigação se faz pertinente quando olhamos para a realidade brasileira. Estamos num país marcado pelo insucesso escolar em Matemática, o que se projeta para o futuro se continuarmos repetindo as mesmas práticas que já se mostraram ineficientes? Como mudar a situação do ensino de Matemática sem rever as relações de ensino e aprendizagem e, principalmente, sem pensar em preparar professores capazes de orquestrar tais mudanças?

A preocupação com a situação atual transparece também nos documentos oficiais, que procuram garantir, a partir de suas orientações e até por força de lei, que sejam oferecidas condições aos futuros professores, de atuar de forma a praticar a Matemática necessária à cidadania ainda durante seus cursos, nos estágios. Isso envolve muito mais do que conteúdos matemáticos propriamente ditos. Significa preparar o professor para que seja 
capaz de atuar junto aos seus futuros alunos de modo que sua compreensão da Matemática permita interpretar fatos e notícias, usar raciocínio lógico matemático para tomar decisões, analisar e inferir sobre a realidade.

Em oposição aos planejamentos que propõe uma hierarquia de conteúdos e procedimentos que encaminham o aluno numa transição (quase linear) do "mais fácil" ao "mais difícil", o que foi apresentado para análise dos professores em formação foram atividades que, apesar de abordarem conteúdos matemáticos, dão maior ênfase às relações que o aluno pode construir acerca da Matemática do que com o conteúdo em si.

Nesse contexto, a análise bibliográfica e documental sugere que um investimento forte em resolução de problemas parece essencial, dado seu enorme potencial de mobilizar os conhecimentos matemáticos e desenvolver competências, habilidades e atitudes. Neste trabalho, exploramos uma categoria especial de problemas, aqueles que por suas características são classificados como "de Investigação". O trabalho com investigação nas aulas de Matemática influi positivamente na qualidade da aprendizagem dos alunos, conforme relatos de grupos de professores coordenados por Ponte e Fiorentini, utilizados como base desta dissertação.

Ao longo do desenvolvimento deste trabalho, entre idas e vindas que resultaram em uma mudança de percurso, nos deparamos com algo que realmente inquietante: a necessidade de mudança. Essa necessidade, tão bem descrita pelos autores pesquisados, se faz concreta no depoimento dos professores que contribuíram para este trabalho. Estudamos, então, a concepção de professores em formação a respeito de uma mudança em especial, o uso de atividades de investigação nas aulas de Matemática, entendendo que a formação é determinante para a implementação de qualquer prática pedagógica.

A questão é que formação não implica, necessariamente em mudança, mas mudança requer formação. Segundo Baldino, "considerando as centenas de programas de formação de professores de matemática existentes, parece que, não só o ensino e aprendizagem, mas, também, todos os esforços para produzir um compromisso de mudança entre os egressos fracassam". (in 
BICUDO, 1999, p.224)

Mas o que constatamos, na presente pesquisa, é que alunos do curso de Licenciatura continuam vivendo, no seu dia a dia, um ensino que poucas vezes privilegia novas práticas mas que, mesmo assim, vislumbram com certo entusiasmo novas possibilidades. Quando questionados especificamente sobre as atividades de investigação, alunos de Licenciatura em diferentes fases de sua formação afirmam que estariam dispostos a implementá-las em seus cursos.

De modo geral, constatamos que as hipóteses para a resistência dos professores à adoção de novas práticas se confirmam nas pesquisas entre os professores em formação, principalmente aqueles que já estão em sala de aula, por força de seus estágios. A quase totalidade dos alunos de Licenciatura pesquisados considera que o envolvimento do aluno, ambiente colaborativo e interação respeitosa ainda não fazem parte da realidade das escolas onde trabalham.

Os questionários também revelam que as condições de trabalho no que se refere à gestão da sala de aula, disciplina, tempo didático são fatores que podem desencorajar professores a adotar novas práticas.

Outro aspecto relevante desse trabalho foi a importância dada ao papel do aluno e do professor no que se refere à prática investigativa. Para que o aluno seja encorajado a elaborar conjecturas, formular, argumentar, deduzir, generalizar, comunicar, etc, agindo como um "matemático profissional", é necessário que o professor saiba atuar de modo a gerenciar os intercâmbios de ideias e conhecimentos que emergem dessa atividade, que saibam fazer as perguntas e intervenções adequadas para potencializar e garantir o compartilhamento do saber produzido por seus alunos. Se, na sua formação, o licenciando não vive, como aluno, esse protagonismo, terá a confiança de "abrir mão" do controle da aula em favor de seus alunos?

Novamente, a resposta dos pesquisados revela uma posição bastante positiva. A maioria dos alunos de Licenciatura pesquisados acredita que trabalhar com atividades de investigação junto a seus alunos pode desenvolver 
potencialidades, aumentar a autoconfiança e melhorar a qualidade da aprendizagem.

Quanto à sua formação acadêmica para trabalhar com atividades diferenciadas, porém, revelam-se mais cautelosos. A questão que pedia para classificar de 0 a 5 o grau de confiança foi a que mostrou maiores discrepâncias (apesar de ninguém ter marcado o zero). Ficou claro que vontade é diferente de confiança para realizar. Então cabe a pergunta: o que acontecerá em um futuro próximo, quando os atuais alunos-professores (estagiários) tornarem-se os professores responsáveis por suas turmas? Irão reproduzir a escola que conheceram ou buscarão novas práticas?

A grande maioria dos alunos de Licenciatura pesquisados também afirmou não se sentir preparada para "novas práticas" com seus alunos. Antes mesmo de formados imaginam que deverão passar por outros cursos de formação com esse objetivo.

Encerramos este trabalho, esperando que os temas aqui abordados possam, de alguma forma, contribuir para futuras reflexões a respeito da formação de professores para a inserção de atividades investigativas, que se mostraram tão relevantes para a melhoria da aprendizagem da Matemática nos lugares onde foram implementadas. O texto a seguir, de Patrícia Sadovsky (2011) , faz um convite à essa reflexão:

Nessa realidade adversa e diversificada em que hoje vivemos e atuamos, há um conhecimento acumulado que permite definir algumas condições que abrem a possibilidade de pensar em "jogar outro jogo" dentro da escola. São experiências em pequena escala, criadas e sustentadas pelo trabalho coletivo de grupos de docentes que têm que acreditar no que fazem. Essas condições, geradas por algumas experiências, não são externas aos sujeitos que as produzem, nem estão completamente moldadas pela situação social e cultural dos seus protagonistas. Elas resultam de uma intenção (que inclui uma vontade, mas a excede totalmente). Falar dessas 
condições com quem está se preparando para ser professor nos dá otimismo. 


\section{REFERÊNCIAS BIBLIOGRÁFICAS}

D'AMORE, BRUNO; (2007) "Elementos de Didática da Matemática" (tradução Maria Cristina Bonomi). Editora Livraria da Física. São Paulo.

BICUDO, M.A.V. (org) (1999) "Pesquisa em Educação Matemática: concepções e perspectivas". Coleção Seminários \& Debates. Ed. UNESP.

BRASIL. (1998) Ministério da Educação. Secretaria de Educação Fundamental. "Parâmetros Curriculares Nacionais". Brasília. 148 p.

. (2015) Ministério da Educação. Conselho Nacional de Educação. Conselho Pleno. "Resolução $n^{\circ} 2$ de $1^{\circ}$ de julho de 2015. Brasília. 16 p.

CHEVALLARD, Y. ; BOSCH, M. ; GASCÓN, J. (2001) "Estudar Matemáticas: O elo perdido entre o ensino e a aprendizagem". Porto Alegre. Artmed Editora.

CRESWELL, J.W. (2007) "Projeto de Pesquisa: métodos qualitativo, quantitativo e misto". Tradução de Luciana de Oliveira da Rocha. $2^{a}$ ed. Porto Alegre. Artmed Editora.

FIORENTINI, D. ; GRANDO, R. C. ; MISKULIN, R. G. S. (2009) "Práticas de Formação e de Pesquisa de Professores que Ensinam Matemática". Campinas. Mercado de Letras.

FIORENTINI, D. ; NACARATO A.M. (org) (2005) "Cultura, formação e Desenvolvimento Profissional de Professores que Ensinam Matemática: investigando e teorizando a partir da prática". Campinas. Musa Editora.

GIL, A.C. (2010) "Como elaborar Projetos de Pesquisa”. 5 ed . São Paulo. Ed. Atlas. 
LINS, R. C. ; GIMENEZ, J. (1997) "Perspectivas em aritmética e álgebra para o século XXI". Coleção Perspectivas em Educação Matemática. Campinas. Papirus.

MACHADO, N. J. (2011). "Matemática e Língua Materna: análise de uma impregnação mútua". São Paulo. Cortez.

PONTE, J. P. da, BROCARDO, J. ; OLIVEIRA, H. (2003). "Investigações Matemáticas na Sala de Aula". Coleção Tendências em Educação Matemática. Belo Horizonte. Autêntica.

SADOVSKY, P. (2011) "O Ensino de Matemática Hoje - Enfoques, sentidos e desafios". Tradução de Antonio de Padua. São Paulo, Ed. Ática

SANTOS, V. de M. (2014). "Ensino de Matemática na Escola de nove anos: dúvidas, dívidas e desafios". Coleção Ideias em Ação. São Paulo. CENGAGE Learning.

\section{ARTIGOS UTILIZADOS NA PESQUISA}

PONTE, J. P. da (03/2010) "Explorar e Investigar em Matemática: Uma atividade Fundamental no Ensino e na Aprendizagem". UNIÓN Revista Iberoamericana de Educación Matemática. Número 21, páginas 13 a 30 .

PONTE, J.P.da (2003) "Investigar, ensinar e aprender". Actas do Profmat 2003. Disponivel em http://www.educ.fc.ul.pt/docentes/jponte/docs-pt/03Ponte(Profmat).pdf

ENTREVISTAS UTILIZADAS NA PESQUISA

BROUSSEAU, G. (2009) "A Cultura Matemática é um instrumento para a cidadania". 
https://novaescola.org.br/conteudo/545/guy-brousseau-a-cultura-matematica-eum-instrumento-para-a-cidadania

SADOVSKY, P. (2007) "Falta Fundamentação Didática no Ensino de Matemática"

https://novaescola.org.br/conteudo/925/falta-fundamentacao-didatica-noensino-da-matematica

\section{ANEXOS}

\section{QUESTIONÁRIO}

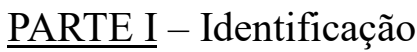

Nome

e-

mail

1) Você trabalha ou já trabalhou como professor? 
( ) Sim, na rede pública

( ) Sim, em escola particular

( ) Nunca trabalhei como professor

( ) Já dei aulas particulares

2) Você pretende exercer a profissão de professor

( ) $\operatorname{Sim}($ ) Não ( ) Ainda não me decidi

3) Você se sente qualificado para atuar junto aos seus alunos aplicando quais das práticas abaixo?

\begin{tabular}{|c|c|c|c|c|}
\hline $\begin{array}{l}\text { ( }) \\
\text { Verificação } \\
\text { aplicação de } \\
\text { propriedades } \\
\text { matemáticas }\end{array}$ & $\begin{array}{l}( \\
\text { Exercícios }\end{array}$ & $\begin{array}{l}\text { ( ) Leitura e } \\
\text { interpretação } \\
\text { de textos } \\
\text { matemáticos }\end{array}$ & $\begin{array}{l}\text { ( }) \\
\text { Discussões em } \\
\text { grupos }\end{array}$ & $\begin{array}{l}\text { ( } \\
\text { Comunicação } \\
\text { de ideias } \\
\text { matemáticas }\end{array}$ \\
\hline $\begin{array}{ll} & ( \\
\text { Atividades de } \\
\text { investigação }\end{array}$ & $\begin{array}{l}(\quad) \text { Provas } \\
\text { individuais } \\
\text { escritas }\end{array}$ & $\begin{array}{l}(\quad) \text { Aulas } \\
\text { expositivas }\end{array}$ & $\begin{array}{l}\text { ( ) Treino } \\
\text { dos algoritmos } \\
\text { e das técnicas } \\
\text { de cálculo }\end{array}$ & $\begin{array}{l}\text { ( ) Questões } \\
\text { que envolvem } \\
\text { argumentação e } \\
\text { justificativas }\end{array}$ \\
\hline $\begin{array}{l}( \\
\text { Atividades } \\
\text { experimentais } \\
\text { e jogos }\end{array}$ & $\begin{array}{l}(\quad) \text { Cálculo } \\
\text { mental }\end{array}$ & $\begin{array}{ll} & \\
\text { Resolução de } \\
\text { problemas }\end{array}$ & $\begin{array}{l}(\quad) \text { Uso de } \\
\text { recursos } \\
\text { multimídia }\end{array}$ & $\begin{array}{lr} & \text { ( } \\
\text { Estratégias } & \text { de } \\
\text { revisão } & \mathrm{e} \\
\text { análise } & \text { de } \\
\text { erros. } & \end{array}$ \\
\hline
\end{tabular}




\section{II - Projeto Pedagógico}

1) Imagine que você está elaborando seu planejamento. Separe as atividades abaixo em três grupos, de acordo com critérios criados por você. Escolha um título para cada grupo criado:

\begin{tabular}{|c|c|c|c|c|}
\hline $\begin{array}{l}\text { ( }) \\
\text { Verificação e } \\
\text { aplicação de } \\
\text { propriedades } \\
\text { matemáticas }\end{array}$ & $\begin{array}{l}( \\
\text { Exercícios }\end{array}$ & $\begin{array}{l}\text { ( ) Leitura e } \\
\text { interpretação } \\
\text { de textos }\end{array}$ & $\begin{array}{l}( \\
\text { Discussões em } \\
\text { grupos }\end{array}$ & $\begin{array}{l}\text { ( }) \\
\text { Comunicação } \\
\text { de ideias } \\
\text { matemáticas }\end{array}$ \\
\hline $\begin{array}{l}\text { ( } \\
\text { Atividades de } \\
\text { investigação }\end{array}$ & $\begin{array}{l}\text { ( ) Provas } \\
\text { individuais } \\
\text { escritas }\end{array}$ & $\begin{array}{l}(\quad) \text { Aulas } \\
\text { expositivas }\end{array}$ & $\begin{array}{l}\text { ( ) Treino } \\
\text { dos algoritmos } \\
\text { e das técnicas } \\
\text { de cálculo }\end{array}$ & $\begin{array}{l}\text { ( ) Questões } \\
\text { que envolvem } \\
\text { argumentação e } \\
\text { justificativas }\end{array}$ \\
\hline $\begin{array}{l}( \\
\text { Atividades } \\
\text { experimentais } \\
\text { e jogos }\end{array}$ & $\begin{array}{l}\text { ( ) Cálculo } \\
\text { mental }\end{array}$ & $\begin{array}{ll} & \\
\text { Resolução de } \\
\text { problemas }\end{array}$ & $\begin{array}{l}(\quad) \text { Uso de } \\
\text { recursos } \\
\text { multimídia }\end{array}$ & $\begin{array}{lr}( & \text { ) } \\
\text { Estratégias } & \text { de } \\
\text { revisão } & \mathrm{e} \\
\text { análise } & \text { de } \\
\text { erros. } & \end{array}$ \\
\hline
\end{tabular}

Título:

GRUPO

2) Pode-se ler nos PCN's:

“Assim, o professor deve organizar seu trabalho de modo que os alunos desenvolvam a 
própria capacidade para construir conhecimentos matemáticos e interagir de forma cooperativa com seus pares, na busca de soluções para problemas, respeitando o modo de pensar dos colegas e aprendendo com eles". (p.63)

Marque com um $\left(^{*}\right)$, no quadro acima, cinco atividades que, na sua opinião, favorecem a elaboração de um curso que seja coerente com as indicações dos PCN's.

Nome:

Imagine que você tenha aplicado essa atividade para seus alunos e responda:

1. Que dificuldades você acha que os alunos podem encontrar para realizar a tarefa?

2. A discussão desse problema entre os alunos favorece a aprendizagem? Por quê? 
3. Esse não é um tipo de atividade que se encontra facilmente em livros didáticos. Diga uma característica que diferencia essa atividade das "convencionais" no ensino da relação fração/quantidade.

4. Obviamente poderíamos propor uma atividade como essa só usando números, como: "Maria comprou $3 / 4$ de quilo de carne e pagou $R \$ 15,00$. Quanto pagaria por $1 / 2$ quilo?" Cite duas vantagens e duas desvantagens que você identifica para trabalhar com o problema a partir das tiras de papel.

\begin{tabular}{|l|l|}
\hline DESVANTAGENS & VANTAGENS \\
\hline & \\
\hline & \\
& \\
\hline
\end{tabular}

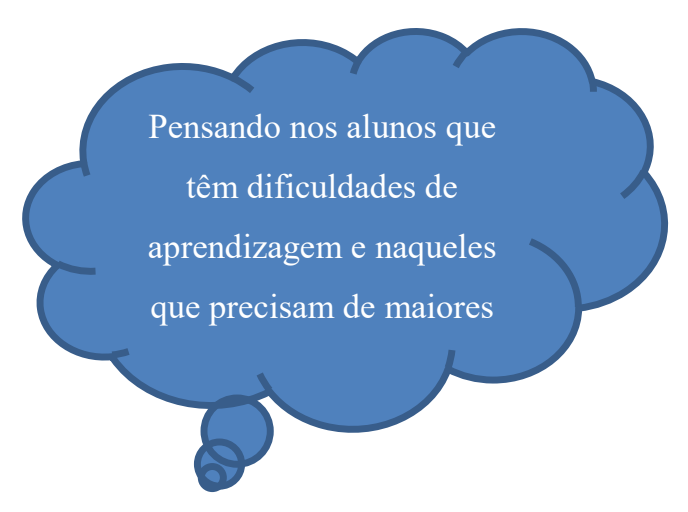


5. O que poderia ser modificado nessa atividade para que ela se tornasse mais fácil?

6. O que poderia ser modificado nessa atividade de modo a torná-la mais difícil?

7. Na atividade com as frações você foi convidado a assumir o papel do aluno. Como você avalia essa experiência?

( ) Gostei, pois

( ) Não gostei, pois

A partir de agora, fale sobre sua experiência como aluno da Licenciatura:

8. No curso de Licenciatura em Matemática você diria que realizou atividades como a descrita acima

( ) Muitas vezes

( ) Poucas vezes

( ) Raramente 
9. Você pretende incorporar à sua pratica, como professor, atividades que envolvem investigação, como a que acaba de realizar? Justifique.

10. Você diria que, no curso de Licenciatura, teve a oportunidade de vivenciar diferentes práticas (inclusive a investigativa) e que isso forneceu os subsídios necessários para trabalhar com atividades diversificadas em sala de aula, com seus futuros alunos?

( ) Sim, sinto-me confiante para trabalhar com diferentes práticas.

( ) Mais ou menos, acho que ainda precisarei de novos cursos de formação.

( ) Não, acho que terei dificuldade em realizar um trabalho desse tipo. 


\section{Questionário 2}

Olá,

Meu nome é Paola Burgatt Meneghesso, sou aluna do Mestrado Profissional em Ensino de Matemática, estudando as possibilidades de trabalho com atividades de investigação nas aulas de Matemática do EF2.

Esse questionário tem como objetivo verificar a aceitação desse tipo de atividade entre os professores e discutir a viabilidade de aplicação das atividades de investigação nas aulas.

Esclareço que estamos aqui falando de atividade de investigação no sentido de Ponte*, cujas principais características são:

- O ponto de partida é uma situação aberta, ou seja, não se trata de um problema onde todos os dados estão definidos. Cabe ao aluno a tarefa de mobilizar seus recursos para formalizar questões e concretizar a proposta. Assim, o envolvimento do aluno desde o início da tarefa é fundamental.

- Trata-se de uma situação absolutamente colaborativa, pois é a partir da discussão sobre as questões elaboradas pelos alunos acerca do problema que se traçam possíveis estratégias de resolução.

- Atividades de investigação colocam o aluno em uma situação de protagonismo. Enquanto busca resolver o problema o aluno "produz Matemática", desenvolve procedimentos, aplica técnicas e, principalmente, experimenta, testa, argumenta, justifica, prova, explica, numa atitude se aproxima do que fazem os matemáticos em sua prática acadêmica.

No ano passado foi aplicado um primeiro questionário em uma turma de Licenciatura do IME/USP, como um teste, a partir da atividade de investigação abaixo relatada. Os professores realizaram uma atividade com frações e responderam questões sobre sua aplicabilidade em sala de aula e sobre sua percepção quanto à eficiência desse tipo de 
proposta para o ensino. Também foi investigada a percepção da turma sobre sua formação para essa prática.

Dando continuidade, peço que o questionário abaixo seja respondido de acordo com sua prática atual e suas convicções a respeito do trabalho com Matemática no Ensino Fundamental 2. Agradeço por sua participação e colaboração!

Para garantir a credibilidade desse documento, peço que se identifique (sua identidade não será divulgada):

Nome:

e-mail (opcional)

\section{QUESTÕES}

2. Você já conhece ou usa atividades de investigação na sua prática? Fale brevemente sobre sua experiência.

3. Já sendo experiente ou mesmo que nunca tenha trabalhado com atividades de investigação, classifique de 0 a 3 seu grau de afinidade com esse tipo de proposta (Use 0 para não me identifico e 3 para me identifico totalmente). Comente sua opção de resposta.
( $) 0$
( ) 1
( ) 2
( ) 3

4. Se você já inclui atividades de investigação em seu planejamento, cite uma que já tenha aplicado. 
Sobre a atividade de frações mencionada anteriormente:

Segue a atividade:

Você está recebendo uma tira de papel azul cujo comprimento representa $3 / 4$ de certa quantidade. Use as outras tiras para representar as seguintes frações (todas relativas à mesma quantidade):
a) $2 / 3$ do total
b) $5 / 8$ do total
c) $3 / 2$ do total
d) $2 / 5$ do total

Foram fornecidas outras tiras de papel, com comprimento maior do que o da tira azul, para a realização da atividade.

5. a) Quanto à afirmação: "O ponto de partida é uma situação aberta, ou seja, não se trata de um problema onde todos os dados estão definidos. Cabe ao aluno a tarefa de mobilizar seus recursos para formalizar questões e concretizar a proposta"

$\mathrm{Na}$ sua opinião, como essas características se revelam na proposta (ser um problema aberto, necessitar de uma etapa de questionamento inicial, o aluno terminar a formulação do problema)?

6. Quais os aspectos que diferenciam essa atividade dos problemas normalmente propostos no ensino de frações? 
7. Imagine que você vá usar essa atividade com seus alunos. Quais seriam suas dificuldades? Você acha a proposta viável? Justifique.

8. Comente se sua formação acadêmica foi favorável ou desfavorável para o trabalho com atividades de investigação.

9. Comente se suas condições de trabalho são favoráveis ou desfavoráveis para o trabalho com atividades de investigação.

10. Informe:

Local de trabalho:

Função/série em que atua: 


\section{Questionário 3}

Boa noite, meu nome é Paola Burgatt Meneghesso, sou aluna do Mestrado Profissional em Ensino de Matemática da USP e estou fazendo uma pesquisa sobre "Atividades de Investigação em sala de aula". Com este questionário espero obter informações sobre a disponibilidade de professores (ou futuros professores) para inserir, em sua prática, atividades desse tipo.

Essa pesquisa será realizada em 3 momentos:

1- Parte 1 do questionário (Identificação e primeira aproximação com o tema)

2- Vivência - Realizaremos uma atividade de investigação seguindo os mesmos passos realizados por duas turmas de alunos de 70 ano. Durante a realização da atividade, farei um breve relato dos resultados obtidos junto a eles na sala de aula.

3- Parte 2 do questionário (Avaliação da atividade e sua aplicabilidade).

\section{QUESTIONÁRIO}

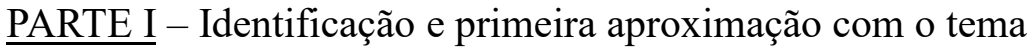

Nome

e-mail

1) Você trabalha ou já trabalhou como professor? 
( ) Sim, na rede pública

( ) Sim, em escola particular

( ) Nunca trabalhei como professor

2) Você pretende exercer a profissão de professor

( ) $\operatorname{Sim}($ ) Não ( ) Ainda não me decidi

3) Você já tinha ouvido falar, estudado, pesquisado sobre Investigação Matemática?

( ) $\operatorname{sim}(\quad)$ não

4) O termo "Atividade de Investigação" refere-se ao trabalho do Prof. Dr. João Pedro da Ponte, da Universidade de Lisboa, que afirma: "Investigar é procurar conhecer o que não se sabe".

Segundo ele, um problema de investigação não precisa ser, necessariamente difícil. “Trata-se de uma questão mais aberta - a questão não está bem definida no início, cabendo a quem investiga um papel fundamental na sua definição"(p.23)

Um exemplo poderia ser: O QUE SE PODE GARANTIR SOBRE OS EIXOS DE SIMETRIA NOS POLÍGONOS REGULARES?

Na sua opinião, esse tipo de problema tem potencial para promover boas situações de aprendizagem? 
5) Ponte questiona, na introdução de seu livro ${ }^{1}$ : "Pode o trabalho de investigação dos matemáticos servir de inspiração para o trabalho a realizar por professores e alunos nas aulas de Matemática"? Importa saber se está ao alcance dos alunos investigar questões matemáticas e de que forma isso pode contribuir para sua aprendizagem. Importa também saber que competências necessitam os professores para promover esse tipo de trabalho em suas aulas e que condições são necessárias para que isso aconteça".

Responda:

Você acha que o trabalho dos matemáticos (formular questões, conjecturas, testar, justificar, analisar) pode ser reproduzido com os alunos? Comente.

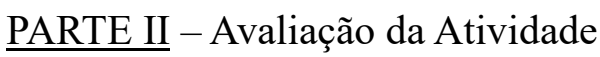

1) Depois de ter vivenciado uma atividade de investigação e ouvido o relato sobre o desempenho dos alunos, responda:

c. Que dificuldades você imagina que um professor pode enfrentar com esse tipo de proposta em sala de aula? 
d. Que dificuldade esse tipo de proposta pode trazer para os alunos?

2) Veja o depoimento de uma professora sobre sua prática com atividades de investigação:

“Penso que as relações mentais que o desenvolvimento de atividades investigativas favorece a aprendizagem significativa, dando ao aluno autonomia para estabelecer relações matemáticas importantes e estruturantes, que pudessem ficar fragilizadas se esse aluno fosse submetido apenas à realização de atividades tradicionais, mecânicas, vazias de sentido."

Classifique de 0 a 5 seu nível de concordância com a professora (0 para não concordo e 5 para concordo plenamente)
( $\quad) 0$
( ) 1
( $\quad) 2$
( ) 3
$(\quad) 4$
( ) 5

3) Sobre a questão "Suas condições de trabalho são favoráveis ou desfavoráveis para trabalhar com investigações?", uma professora da escola pública respondeu: "Os dois, dependemos muito dos gestores da escola". 
Quais as condições de trabalho, na sua opinião, que favorecem a implementação de atividades diferenciadas nas aulas de Matemática? O professor deve ter autonomia para escolher?

4) Você acha que, mesmo em instituições mais fechadas, é possível criar condições para o desenvolvimento de atividades menos tradicionais (como listas de exercícios, atividades individuais, etc)?

5) O trabalho com problemas de investigação pressupõe envolvimento do aluno, ambiente colaborativo e interação respeitosa. Você acha que essas condições estão garantidas nas escolas brasileiras? Comente. 
6) Veja como um professor respondeu à questão "Comente se sua formação acadêmica foi favorável ou desfavorável para o trabalho com atividades de investigação."

Foi favorável, mas poderia ter sido ainda melhor. Vejo que boa parte das coisas que aprendi foram na prática, tendo que ser professor, e não aluno da graduação. Boa parte aprendemos apenas quando lecionamos, e isso é natural, principalmente por ter que investigar os "porquês". Mas, a graduação poderia ter contribuído um pouco mais, para além de importantes reflexões que me foram propostas.

E você?

Sobre sua formação acadêmica, classifique de 0 a 5 seu nível de conforto para trabalhar com atividades diferenciadas, como as de investigação. (Use 0 para não me sinto preparado e 5 para estou plenamente confiante)
( ) 0
( ) 1
( $\quad) 2$
( $\quad) 3$
( ) 4
( ) 5

7) Você estaria disposto a inserir em sua prática atividades de investigação? Comente 
